\title{
User's Guide to DIANE Version 2.1: A Microcomputer Software Package for Modeling Battery Performance in Electric Vehicle Applications
}

by W.W. Marr, W.J. Walsh, and P.C. Symons*

Energy Systems Division, Argonne National Laboratory, 9700 South Cass Avenue, Argonne, Illinois 60439

June 1990

Work sponsored by United States Department of Energy, Assistant Secretary for Conservation and Renewable Energy, Office of Transportation Systems

"Symons is affiliated with Electrochemical Engineering Consultants, Inc., Morgan Hill, California. 


\section{Contents}

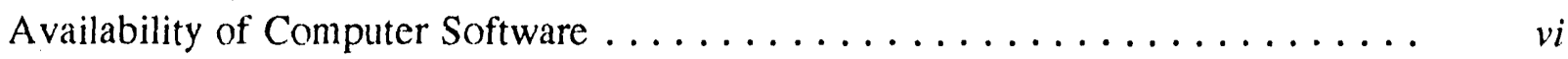

Acknowledgments $\ldots \ldots \ldots \ldots \ldots \ldots \ldots \ldots \ldots \ldots \ldots \ldots$

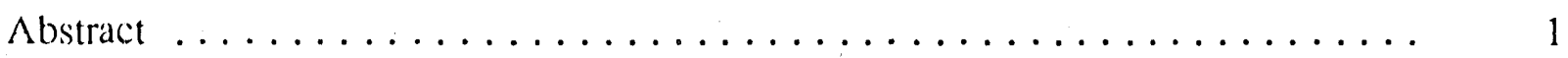

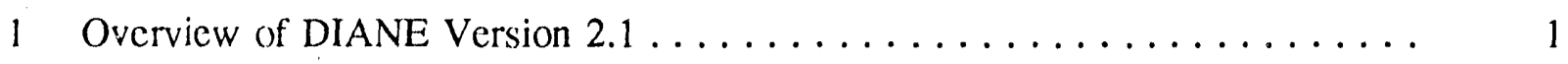

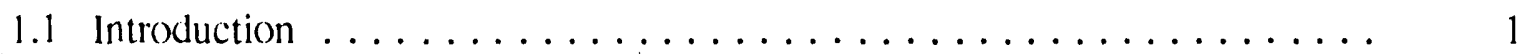

1.2 Development of the Model . . . . . . . . . . . . . . . . . . 2

1.3 Procedure for Calculation of Power Requirement $\ldots \ldots \ldots \ldots \ldots$

1.4 Organization of the Program $\ldots \ldots \ldots \ldots \ldots \ldots \ldots \ldots \ldots \ldots$

2 Description of Input Variables $\ldots \ldots \ldots \ldots \ldots \ldots \ldots \ldots \ldots \ldots \ldots \ldots \ldots \ldots$

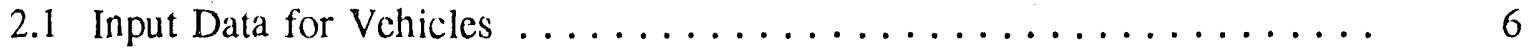

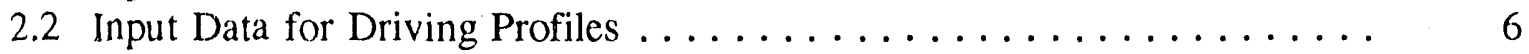

2.3 Input Data for Batteries . . . . . . . . . . . . . . . 7

3 Program Operation and Output Information $\ldots \ldots \ldots \ldots \ldots$

3.1 Step-by-Step Operation of DIANE Version $2.1 \ldots \ldots \ldots \ldots$

3.2 Sample Problems ......................... 14

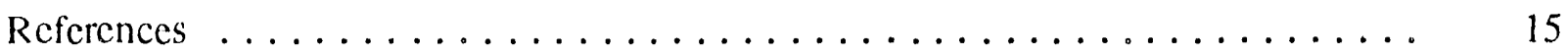

Appendix A: Calculation of Power Requirement . . . . . . . . . . 17

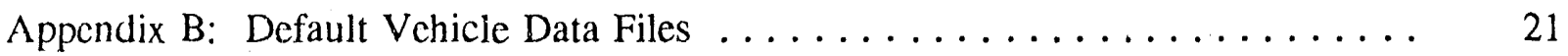

Appendix C: Default Driving Profile Data Files ................. 27

Appendix D: Default Battery Data Files $\ldots \ldots \ldots \ldots \ldots \ldots \ldots$

Appendix E: Sample Problems . . . . . . . . . . . . . . . . 43

\section{Figure}

A.1 Schematic Diagram of Forces Acting on a Vehicle . . . . . . . . . . 20 


\section{Tables}

1.1 Program Organization of DIANE Version $2.1 \ldots \ldots \ldots \ldots \ldots$

2.1. Input Data for Vchiclc Simulation $\ldots \ldots \ldots \ldots \ldots \ldots \ldots \ldots$

2.2 Input Data for Driving Profile Data File . . . . . . . . . . . . . 8

2.3 Input Data for Power Profile Data File $\ldots \ldots \ldots \ldots \ldots$

2.4 Input Data for Battcry Data File $\ldots \ldots \ldots \ldots \ldots \ldots \ldots \ldots \ldots \ldots \ldots \ldots \ldots \ldots$

3.1 Sample Problems $\ldots \ldots \ldots \ldots \ldots \ldots \ldots \ldots \ldots \ldots \ldots \ldots \ldots \ldots$

B.1 Default Vehicle Data Set for the Eaton Dual-Shaft Electric Propulsion

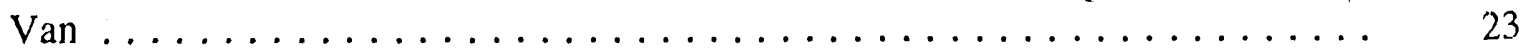

B.2 Default Vehicle Data Set for the Improved Dual-Shaft Electric Propulsion

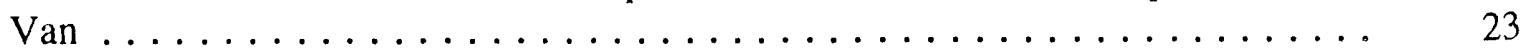

B.3 Default Vehicle Data Set for the Griffon Electric Van . . . . . . . . . . 24

B.4 Default Vehicle Data Set for the Second-Generation Single-Shaft Electric Propulsion System . . . . . . . . . . . . . . . . . . . . . 24

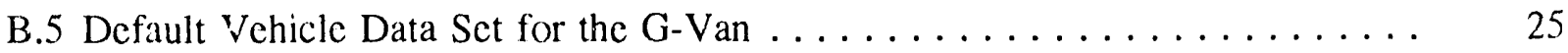

B.6 Default Vehicle Data Set for the TEVan . . . . . . . . . . . . . 25

B.7 Default Vehicle Data Set for the Improved Electric Test Vehicle $\ldots \ldots \ldots \ldots$

B.8 Default Vehicle Data Set for the Impact $\ldots \ldots \ldots \ldots \ldots \ldots \ldots \ldots \ldots \ldots \ldots \ldots$

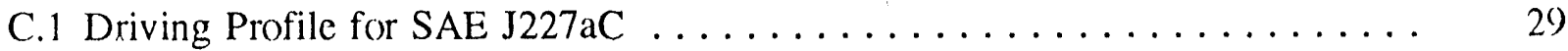

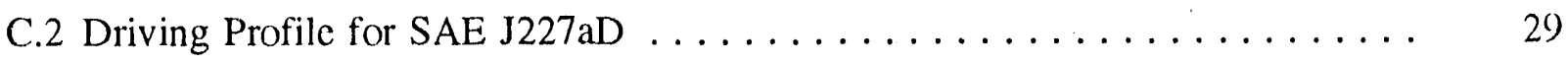

C.3 Simplified Federal Urban Driving Schedule, Velocity Slightly Changed . . . . . 30

C.4 Power Profile at Battery Terminals for $\mathrm{J} 227 \mathrm{aD}$ and the Improved Electric Test Vehicle ............................... 


\section{Tables (Cont'd)}

C.5 Power Profile at Battery Terminals for the Simplified Federal Urban

Driving Schedule and the Improved Dual-Shaft Electric Propulsion Van . . . . 33

D.1 Default Data Set for Sodium/Sulfur Batteries, 1988 Technology . . . . . . . . 37

D.2 Default Data Set for Sodium/Sulfur Batteries, 1989 Technology . . . . . . . . 38

D.3 Default Data Set for Nickel/Iron NIF220 Batteries . . . . . . . . . . . 39

D.4 Default Data Set for Tubular L/A 3ET205 Ratterics . . . . . . . . . . 40

D.5 Default Data Set for Zinc/Bromine Batteries $\ldots \ldots \ldots \ldots \ldots \ldots$ 


\section{Availability of Computer Software}

This computer software has been developed under the sponsorship of the United States Department of Energy (DOE). Any further distribution by any holder of the software packige or other data therein outside of DOE offices or other DOE contractors, unless otherwise specifically provided for, is prohibited without the approval of the National Energy Software Center. Requests from outside the Department of Energy for DOE-developed computer soltware shall be directed to the Director, National Energy Software Center, Argonne National Laboratory, 9700 South Cass Avenuc, Argonne, Illinois 60439. 


\section{Acknowledgments}

We want to thank the following individuals for reviewing and commenting on this report and for trying out the DIANE 2.1 software package: Albert Koenig of Beta Power, Inc.; Matthew Dzicciuch of Ford Motor Company; Andrew Burke of Idaho National Enginecring Laboratory (INEL); and James Miller of Argonne National Laboratory (ANL). We would also like to thank Kevin Brown of ANL, who edited the text, and Joyce Henry, also of ANL, who provided word-processing support. 


\title{
User's Guide to DIANE Version 2.1:
}

\section{A Microcomputer Software Package for Modeling Battery Performance in Electric Vehicle Applications}

by

\author{
W.W. Marr, W.J. Walsh, and P.C. Symons
}

\begin{abstract}
DIANE is an interactive microcomputer software package for the analysis of battcry performance in clectric vehicle (EV) applications. The principal objective of this sof tware package is to cnable the prediction of $\mathrm{EV}$ performance on the basis of laboratory test data for batteries. The model provides a second-by-second simulation of battery voltage and current for any specified velocity/time or power/time profile. The capability of the battery is modeled by an algorithm that relates the battery voltage to the withdrawn current, taking into account the effect of battery depth-ofdischarge (DOD). Because of the lack of test data and other constraints, the current version of DIANE deals only with vchicles using "fresh" batteries* with or without regencrative braking. Deterioration of battery capability duc to aging can presently be simulated with user-input parameters accounting for an increase of effective internal resistance and/or a decrease of cell noload voltage. DIANE 2.1 is written in FORTRAN language for use on IBMcompatible microcomputers.
\end{abstract}

\section{Overview of DIANE Version 2.1}

\subsection{Introduction}

In electric vehicle (EV) applications, the relationship between the performance of a battery and its operational history is extremely complex. The energy and power capabilitics of the battery are generally influeneed by the nature and number of discharges that the battery has cxperienced, which, in turn, are determined by the velocity/time profiles and the driving pattem of the vehicle. Evidence of the complexity of the relationship may be found in the occasionally

\footnotetext{
*An algorithm for simulating the aging and recuperation effects of batteries was included in a previous version of DIANE (Marr, Walsh, and Symons 1987).
} 
poor correlation between the results of laboratory testing of EV battery modules, the results of dynamometer or track testing of EV performance, and the actual in-use ranges and accelerations that have been observed in precommercial demonstrations.

Numerous attempts have been made to analytically describe battery performance so that EV performance can be projected. Such attempts include the fractional utilization model in ELVEC (Slusser, Chapman, and Chazanoff 1982) and the design algorithms in MARVEL (Marr and Walsh 1984). In most cases, oversimplified or generalized representations of battery performance were used. The state of battery modeling has not yet advanced to the point where it is possible to uniquely determine the performance of a battery at any point in its life by analytically solving a set of equations. However, the simulation process employed in DIANE, which is described in this report, has the objective of cnabling accurate predictions of EV performance by relating battery performance and empirical characteristics of the battery.

\subsection{Development of the Model}

The most fundamental assumption in the DIANE formulation is that the voltage of a battery cell under load can be represented, at any point in its discharge, by the simple electrical equation:

$$
V=V_{0}-I R
$$

where:

$$
\begin{aligned}
& \mathrm{V}=\text { the voltage of a cell being discharged }(\mathrm{V}) \\
& \mathrm{V}_{\mathrm{O}}=\text { the cffective no-load voltage, or NLV }(\mathrm{V}) ; \\
& \mathrm{I}=\text { the discharge current }(\mathrm{A}) ; \text { and } \\
& \mathrm{R}=\text { the effective internal resistance of the cell }(\Omega) .
\end{aligned}
$$

At any given time during the discharge cycle, the relationship between battery voltage and the current is more complicated than is indicated in the simple formulation given in Eq. 1 . The internal resistance of a battery cell can rarely be represented by a simple ohmic resistance; among other effects, the effective resistance often varies with discharge rate. However, inspection of the discharge current/voltage curves for a number of batteries shows that, over the range of discharge rates and periods of discharge at these rates that are likely to be used in EVs, the formulation given in Eq. 1 is a reasonable approximation, provided that the parameters $V_{0}$ and $R$ are properly defined.

The effective no-load voltage, $V_{0}$, is the $y$-intercept of an extrapolated plot of voltage versus current for the cell over the rates and periods of discharge that are of interest for EV applications. Similarly, the effective resistance, $\mathrm{R}$ in Eq. 1, is the slope of the voltage/current plot just described. 
In the present version of DIANE, empirical values of $\mathrm{V}_{0}$ and $\mathrm{R}$, obtained from laboratory test data, are input as functions of the depth-of-discharge (DOD); thus,

$$
\mathrm{V}_{\mathrm{o}}=\mathrm{f}_{1}(\mathrm{DOD})
$$

and

$$
\mathrm{R}=\mathrm{f}_{2}(\mathrm{DOD})
$$

For the case of regenerative braking, the values of $V_{0}$ and $R$ can be different, and therefo $c$ the following functional relationships are used:

and

$$
\mathrm{V}_{\text {or }}=\mathrm{f}_{3}(\mathrm{DOD})
$$

$$
\mathrm{R}_{\mathrm{T}}=\mathrm{f}_{4}(\mathrm{DOD})
$$

The parameter DOD in Eqs. 2-5 is defined as:

$$
D O D=\frac{\int_{0}^{T} I\left[1+g_{1}\left(\frac{I}{I_{3}}-1\right)\right] d t}{C_{3}}
$$

where:

$$
\begin{aligned}
\mathrm{t}= & \text { time }(\mathrm{h}), \\
\mathrm{T}= & \text { discharge time to reach DOD }(\mathrm{h}), \\
\mathrm{I}_{3}= & \text { the battery current corresponding to a three-hour rate }(\mathrm{A}), \\
\mathrm{C}_{3}= & \text { battery capacity corresponding to } \mathrm{I}_{3}(\mathrm{Ah}), \\
\mathrm{g}_{1}= & \text { a uscr-input, dimensionless parameter simulating the effect of discharge rate on } \\
& \quad \text { capacity. The value of } \mathrm{g}_{1} \text { can be derived from battery test date (c.g., the } \\
& \text { Peukert curve). For most types of batteries, } \mathrm{g}_{1} \text { can be assumed to be zero. }
\end{aligned}
$$

For a battery that is discharged at a three-hour rate or for a battery that has a capacity unaffected by its discharge rate (i.e., $g_{1}=0$ ), Eq. 6 may be simplified to:

$$
\text { DOD }=\frac{\int_{0}^{T} I d t}{C_{3}}
$$

An assumption made in the DIANE formulation is that the characteristics of an EV battery pack can be represented by a typical cell. The capacity of a cell (in ampere-hours) is determined from the discharge time that the cell can sustain at a given discharge current before the terminal voltage falls below a cutoff point. 


\subsection{Procedure for Calculation of Power Requirement}

For a vehicle with specified characteristics, the power requirement at the wheels corresponding to the driving profile is calculated from the required force, which overeomes the drag force, the rolling resistance, the grade, and acceleration and, at the same time, maintains the vehicle at the specified speed. The equations used in the calculation are described in App. A. The battery current and voltage corresponding to the power/time profile are then calculated on a second-by-second basis. Battery power, $\mathrm{P}_{\mathrm{B}}$, at any time, is the product of current, $\mathrm{I}$, and voltage, $V$ (i.e., $P_{B}=I V$ ). For a known battery power requirement $P_{B}$ (see $E q$. A.9), and with the aid of Eq. 1, we have the following quadratic equation that can be solved for I:

$$
R I^{2}-V_{o} I+P_{B}=0
$$

The values of $R$ and $V_{o}$ can be obtained from Eqs. 2 and 3 or Eqs. 4 and 5.

After the instantaneous battery current is calculated, the battery voltage can be computed from Eq. 1. The effective capacity discharged is then updated to include the time increment according to Eq. 6 . The calculation continues for the driv'ng cycles until the battery voltage falls below a cutoff point or the battery current reaches the limit set by the user. The range is obtained by multiplying the number of times the driving profile is repeated by the range of the profile.

\subsection{Organization of the Program}

DIANE 2.1 consists of one main program and several subprograms. The names and functions of these subprograms are listed in Table 1.1. Within each subprogram, there could be more than one subroutine.

In linking compiled object files to produce the execution filc DIANE21.EXE with graphics capability, a library named GRAFEX33.LIB (provided by the GRAFMATIC software package*) was used, in addition to the Microsoft FORTRAN and MATH librarics. An EGA or VGA graphics board is needed for plotting. A version of DIANE 2.1 without the graphics capability, DIANENP.EXE, was produced by omitting the last four statcments about plotting in DIANE21.FOR. The plotting subprogram GRAPH was not included in DIANENP.EXE.

*GRAFMATIC: Scientific/Enginecring Graphics, MICROCOMPATIBLES, 301 Prelude Drive, Silver Springs, Md. 20901 
TABLE 1.1 Program Organization of DIANE Version 2.1

\begin{tabular}{|c|c|c|}
\hline Names & & $\begin{array}{l}\text { Subroutines } \\
\text { Included }\end{array}$ \\
\hline DIANE21 & Main program control; s-by-s EV simulation & RUNEV \\
\hline INPUT1 & $\begin{array}{l}\text { Read and write vehicle and driving } \\
\text { profile input data }\end{array}$ & PINPUT, PPRINT \\
\hline INPUT'2 & Read and write battery input data & DINPUT, DPRINT \\
\hline SIL & $\begin{array}{l}\text { Set up output device; problem initialization; } \\
\text { table look-up }\end{array}$ & $\begin{array}{l}\text { SETPRINT, INIT, } \\
\text { BETWEEN }\end{array}$ \\
\hline INTER & $\begin{array}{l}\text { Interactive modification of preselected } \\
\text { parameters }\end{array}$ & INTERACT \\
\hline POWER & Compute power profile & POWER \\
\hline SPEEDUP & $\begin{array}{l}\text { Compute vehicle speed for maximum-power } \\
\text { acceleration }\end{array}$ & SPEEDUP \\
\hline GRAPH & $\begin{array}{l}\text { Plot maximum currents and minimum voltages } \\
\text { during battery discharge. }\end{array}$ & $\begin{array}{l}\text { DPLOT, PLOTMENU, } \\
\text { PLOTCI, PLOTCV, } \\
\text { PLOTBIKM, BITM, } \\
\text { PLOTBVKM, BVTM }\end{array}$ \\
\hline
\end{tabular}




\section{Description of Input Variables}

Input data arc divided into three categories: vehicle, driving profile, and battery. Respective default data files are included in Apps. B through D. Input data to DIANE can be, changed in either of two ways: (1) by modifying an existing (default) data file through the use of an on-line interactive text editor or (2) by changing the values of the preselected parameters interactively prior to a simulation run.

\subsection{Input Data for Vehicles}

The input data that are needed for vehicle simulation are listed in Table 2.1.

Default data files (shown in App. B for eight types of vehicles) are available in the current version of the DIANE software package. These include the Eaton Dual-Shaft Electric Propulsion Van (DSEP), the Improved Dual-Shaft Electric Propulsion Van (IDSEP), the Gencral Motors (GM) Griffon electric van, the Ford's Second-Generation Single-Shaft Electric Propulsion System (ETX-II), the Electric Power Research Institute's (EPRI) G-Van and TEVan, the Improved Electric Test Vehicle (IETV-1), and GM's two-passenger prototype electric car, the Impact.

\subsection{Input Data for Driving Profiles}

The power requirement of a vehicle depends on the driving profile that the vehicle must negotiate. A driving cycle is assumed to comprise two parts: a driving period followed by a rest period. Currently, the second-by-second velocity data in the driving period are limited to 400 entries. Table 2.2 shows the input data required for the driving profile data file.

Three default driving profiles, shown in App. $\mathrm{C}$, are available in the software package. These profiles include the JPL-Standardized Version of SAE J227a Schedule C, the JPLStandardized Version of SAE J227a Schedule D (Hewitt and Bryant 1982), and the Simplified Federal Urban Driving Schedule (SFUDS). SFUDS is a modification of the Federal Urban Driving Schedule (FUDS) with the power requirement at the battery terminals limited to $79 \mathrm{~W} / \mathrm{kg}$ (DOE 1988).

For the case where power profile instead of velocity profile is specified, the second-bysecond power requirement (based on battery weight) at the battery terminals should be entered as input. Table 2.3 shows the input for a power profile data file.

Two default power data files, J227AD.POW (for the IETV-1 with SAE J227aD driving profile) and SFUDS.POW (for the IDSEP vehicle with a battery wcight of $69.5 \mathrm{~kg}$ ), are also included in the software package and are shown in App. C. 
TABLE 2.1 Inpui Data for Venicle Simulation

\begin{tabular}{|c|c|c|}
\hline inpust Variable & Unit & Comment \\
\hline Title & - & Limited to 75 characters \\
\hline $\begin{array}{l}\text { Curb weight, without } \\
\text { batteries, CWNB }\end{array}$ & $\mathrm{kg}$ & $\begin{array}{l}\text { Vehicle test weight is TW = } \\
\text { CWNB + BW + PLW }\end{array}$ \\
\hline Battery weight, BWV & $\mathrm{kg}$ & Including accessories \\
\hline Drivetrain efficiency, EFFD & - & $\eta_{D}$ in Eq. A9. \\
\hline Motor efficiency, EFFM & - & $\eta_{M}$ in Eq. $A 9$ \\
\hline $\begin{array}{l}\text { Rolling resistance } \\
\text { coefficient, KO }\end{array}$ & - & See Eq. A5 \\
\hline $\begin{array}{l}\text { Rolling resistance } \\
\text { coefficient, } \mathrm{K} 1\end{array}$ & $\sin$ & See Eq. A5 \\
\hline $\begin{array}{l}\text { Rolling resistance } \\
\text { coefficient, } \mathrm{K} 2\end{array}$ & $\mathrm{~s}^{2} / \mathrm{m}^{2}$ & See Eq. A5 \\
\hline Frontal area, FAREA & $m^{2}$ & $A_{F}$ in Eq. $A 4$ \\
\hline Drag coefficiert, CD & - & $C_{D}$ in Eq. A.t \\
\hline Grade, GRADE & $\%$ & $100 \times \tan \theta$; see Fig. A1 \\
\hline Payload, PI W & $\mathrm{kg}$ & $\begin{array}{l}\text { Usuaily half of the maximum } \\
\text { payload }\end{array}$ \\
\hline Maximum vericle veight, GVW & $\mathrm{kg}$ & Vehicle design weight \\
\hline $\begin{array}{l}\text { Controller current limit, } \\
\text { DCOI }\end{array}$ & A & $\begin{array}{l}\text { Voltage limit is set at cell level in } \\
\text { BATTERY input data below }\end{array}$ \\
\hline
\end{tabular}

\subsection{Input Data for Batteries}

Input variables for a battery data file are listed in Table 2.4 .

Five default battery data files are included in the DIANE software package (see App. D). Battcry characteristics are based on test data from the Analysis and Diagnostic Laboratory (ADL) at Argonne National Laboratory (DeLuca et al. 1989; Miller 1989). The Na/S 1988 data file represents the $1988 \mathrm{CSPL} \mathrm{Na/S}$ cell rechnology (as demonstrated in the 24-cell, 8-V module), and the Na/S 1989 data file represents the 1989 cell technology (as demonstrated in the 960-cell, 
TABLE 2.2 Input Data for Driving Profile Data File

\begin{tabular}{lll}
\hline \multicolumn{1}{c}{ Input Variable } & Unit & \multicolumn{1}{c}{ Comment } \\
\hline Title & - & $\begin{array}{l}\text { Limited to } 75 \\
\text { characters } \\
\text { Including rest time }\end{array}$ \\
Cycle time, TC & $\mathrm{s}$ & \\
Rest time, TREST & $\mathrm{s}$ & $\mathrm{N}=1$ to TC-TREST; \\
Second-by-second velocity, & $\mathrm{km} / \mathrm{h}$ & 400 maximum entries \\
VELO(N) & & \\
\hline
\end{tabular}

TABLE 2.3 Input Data for Power Profile Data File

\begin{tabular}{lll}
\hline \multicolumn{1}{c}{ Input Variable } & Unit & \multicolumn{1}{c}{ Comment } \\
\hline Title & - & $\begin{array}{l}\text { Limited to } 75 \\
\text { characters } \\
\text { Including rest time }\end{array}$ \\
Cycle time, TC & $\mathrm{s}$ & \\
Rest time, TREST & $\mathrm{s}$ & Distance per profile \\
Cycle range, RC & $\mathrm{km}$ & $\mathrm{N}=1$ to TC-TREST; \\
$\begin{array}{l}\text { Second-by-second power } \\
\text { demand, DPO(N) }\end{array}$ & $\mathrm{W} / \mathrm{kg}$ & 400 maximum entries \\
\hline
\end{tabular}

64-V one-third battery). Also included in the software package are data files based on $220-\mathrm{A} \cdot \mathrm{h}$ $\mathrm{Ni} / \mathrm{Fe}$ modules (NIF220) made by Eagle-Picher Industries (EPI), 6-V tubular lead-acid modules (3ET205) made by Chloride EV Systems Ltd., and 5-kWh, 48-V zinc/bromine module made by S.E.A., Austria. 
TABLE 2.4 Input Data for Battery Data File

\begin{tabular}{|c|c|c|}
\hline Input Variable & Unit & Comment \\
\hline Title & - & Limited to 75 characters \\
\hline Net cell weight, WC & $\mathrm{kg}$ & With no burden \\
\hline Accessory weight/cell, WY & $\mathrm{kg}$ & \\
\hline $\begin{array}{l}\text { Number of parallel strings } \\
\text { in battery, NPS }\end{array}$ & - & \\
\hline $\begin{array}{l}\text { Cell capacity @ C/3 } \\
\text { rate, C3 }\end{array}$ & $A \cdot h$ & \\
\hline Coefficient, DCOV1 & V & $\begin{array}{l}\text { Cell cutoft voltage } \\
\text { CO }{ }^{\prime}=\text { DCOV1 + DCOV2 } \cdot I \max \end{array}$ \\
\hline Coefficient, DCOV2 & V/A & Im $F_{A} x$ is cell maximum current \\
\hline $\begin{array}{l}\text { Number of }(D O D, V O) \text { data } \\
\text { pairs, MV }\end{array}$ & - & Cell no-load voltages \\
\hline Cell $\left(D O D, V_{0}\right)$ data pairs &,$- V$ & see Eq. 2 \\
\hline $\begin{array}{l}\text { Number of }(D O D, R) \text { data } \\
\text { pairs, MR }\end{array}$ & - & Cell resistances \\
\hline Cell $(D O D, R)$ data pairs &,$- \Omega$ & See Eq. 3 \\
\hline $\begin{array}{l}\text { Number of (DOD,Vor) pairs, } \\
\text { MVRG }\end{array}$ & - & Regenerative braking ${ }^{a}$ \\
\hline Cell (DOD,Vor) data pairs &,$- V$ & See Eq. 4 \\
\hline No. of (DOD,Rr) pairs, MRRG & - & Regenerative braking ${ }^{a}$ \\
\hline Cell $(D O D, R r)$ data pairs &,$- \Omega$ & See Eq. 5 \\
\hline Parameter $g_{1}$ & - & See Eq. 6 \\
\hline
\end{tabular}

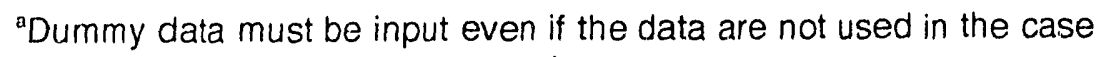
where the braking is not regenerative. 


\section{Program Operation and Output Information}

DIANE 2.1 runs interactively on an IBM-compatible microcomputer. The following describes the step-by-step operation of DIANE 2.1 with graphics capability (DIANE21.EXE). Similar procedures are followed for the version without the graphics capability (DIANENP.EXE).

\subsection{Step-by-Step Operation of DIANE Version 2.1}

1. Copy the contents of the diskette into a subdirectory on your hard disk and run DIANE 2.1 from the hard disk. If you do not have a hard disk, insert the diskette into drive $\mathrm{A}$ and set the default drive to $\mathrm{A}$.

2. Enter DIANE21 to call up the program and for graphics output. If graphics output is not desired, enter DIANENP.

3. You will be asked to specify the output device on which the calculational results are to be displayed or stored. Enter $\mathrm{p}$ (for printer), $\mathrm{c}$ (for console), or d (for disk). If you choose the disk, you will be asked to provide a name for the output filc (the default name DOUT will be used if no file name is given).

4. Upon completion of Step 3, the names of the default data files included in the software package for various vehicles, driving profiles, and battery technologics will be displayed on the screen, as shown below:

\begin{tabular}{|c|c|c|}
\hline \multicolumn{3}{|c|}{${ }^{\star \star \star}$ Select System for Analysis ${ }^{\star \star \star}$} \\
\hline Vehicle & Driving Profile & Battery \\
\hline 1: DSEP & 1: J227aC & 1: $\mathrm{Na} / \mathrm{S} 1988$ \\
\hline 2: IDSEP & 2: J227aD & 2: $\mathrm{Na} / \mathrm{S} 1989$ \\
\hline 3: Griffon & 3: SFUDS & 3: Ni/Fe EPI \\
\hline 4: ETX-11 & 4: User Input & 4: 3ET205 UA \\
\hline 5: G-Van & & 5: $\mathrm{Zn} / \mathrm{Br}$ \\
\hline 6: TEVan & & 6: User Input \\
\hline 7: IETV-1 & & \\
\hline 8: Impact & & \\
\hline 9: User Input & & \\
\hline
\end{tabular}

You can select a default data file by entering the corresponding number for vehicie, driving profile, and battery technology, respectively. Or, you can use your own data file by entering the number signifying user input, followed by the name of the data file. 
5. After you have selected the system for study, you can specify power profile at the battery terminals (W/kg_battery) corresponding to the selected vehicle and driving profile as input instead of being calculated from the velocity profile.

6. Upon completion of Step 5, you can supply a title for identifying the run.

7. Prior to the initiation of a simulation run, certain parameters can be changed interactively. These parameters are shown in the following screen display for sample problem 1 (IETV-1, J227aD, 3ET205):

\begin{tabular}{|c|c|c|c|c|}
\hline INDEX & PARAMETER & COMMENT & UNITS & VALUE \\
\hline . & GVW & Maximum vehicle wt. & $\mathrm{kg}$ & 1837.600 \\
\hline ** & TW & Vehicle test wt. & $\mathrm{kg}$ & 1678.800 \\
\hline 1 & BW & Battery wt. w'accessories & $\mathrm{kg}$ & 488.000 \\
\hline 2 & WO & Net cell weight & $\mathrm{kg}$ & 10.930 \\
\hline 3 & WY & Accessory wt./cell & $\mathrm{kg}$ & .000 \\
\hline 4 & NC & No. of cells in battery & - & 44.648 \\
\hline 5 & NPS & Parallel strings in batt. & - & 1.000 \\
\hline 6 & C3 & Cell Ah@c/3 & Ah & 186.000 \\
\hline 7 & PLW & Vehicle payload & $\mathrm{kg}$ & 158.800 \\
\hline 8 & DCOV1 & cell cutoff voltage comp. 1 & v & 1.300 \\
\hline 9 & DCOV2 & cell cutoff voltage comp. 2 & V/A & .00000 \\
\hline 10 & RF & Resist. factor for aging & - & 1.000 \\
\hline 11 & VF & NLV factor for aging & - & 1.000 \\
\hline 12 & IRG & $>0:$ regenerative braking & - & 1 \\
\hline 13 & IPIN & $>0$ : print input data & - & 0 \\
\hline 14 & IPTEST & $>0$ : print profile results & - & 1 \\
\hline 15 & IIV & $>0$ : print S-by-S I \& V & - & 0 \\
\hline 16 & IACC & $>0$ : accelerate @maxpower & - & 0 \\
\hline $\begin{array}{l}\text { "Input } \\
\text { * Valu }\end{array}$ & $\begin{array}{l}\text { TW must not } \\
\text { outed from oth }\end{array}$ & $\begin{array}{l}\text { eed GVW } \\
\text { put data }\end{array}$ & & \\
\hline
\end{tabular}

To change the value of a particular parameter, enter the corresponding index number. Enter 99 to sec the updated display. Enter 0 to indicate that no more changes will be made and to instruct the prosiam to start computing. The following statements are applicable to specific parameters:

- Note that the program only checks the test weight (TW) againsi the maximum vehicle design weight (GVW). You should make sure that the battery does not exceed its volume limitation.

- The ccll cutoff voltage is assumed to be of the form (DCOV1 + DCOV2 - Imax), where Imax is the maximum cell current in amperes. When the cell cutoff voltage falls below a user-specinied limit, calculation stops.

- The resistance factor, RF, can be used to simulate changes in cell resistance due to battery aging. For a fresh battery, $R F=1$. This factor applies to both the charging (during regenerative braking) and discharging processes. 
- The no-load voltage factor, $\mathrm{VF}$, can similarly be used to account for changes in cell no-load voltage due to aging. For a fresh battery, $V F=1$. This factor applics to both the charging (during regenerative braking) and discharging processes.

- If IRG is a nonzero number (any one-digit integer), regenerative braking is considered in the calculation.

- If IPIN is a nonzero number (any onc-digit integer), input data for vehiclc, driving profile, and battery will be displayed. A second-by-second power profile at the battery terminals, computed on the basis of the input velocity profile and vehicle characteristics, will also be displayed. No velocity profile is displayed if power profile is specified as input.

- If IPTEST is a nonzero number (any one-digit intcger), profile-by-profile calculational data (such as maximum current, minimum voltage, ampere-hours, and kilowatt-hours) will be displayed. Otherwise, an asterisk $\left({ }^{*}\right)$ will be displayed on the screen to signify the completion of a driving profile.

- If IIV is a nonzero number (any one-digit integer), second-by-second currents and voltages of the first and the last driving profiles will be displayed.

- If IACC is a nonzero number (any one-digit integer), the accelcration of a vehicle under the hypothetical case of maximum battery power will be simulated. Second-by-second vehicle speed (up to $80 \mathrm{mph}$ ) and distance will be displayed.

To change parameters not on the preceding list, you can modify any default data filc included in the software package by using a full-screen text editor. Unless you intend to permanently replace the default data file, be sure to assign a different name to your modified data file.

8. At the beginning of the calculation, a summary output similar to the following will bc displayed on the screen:

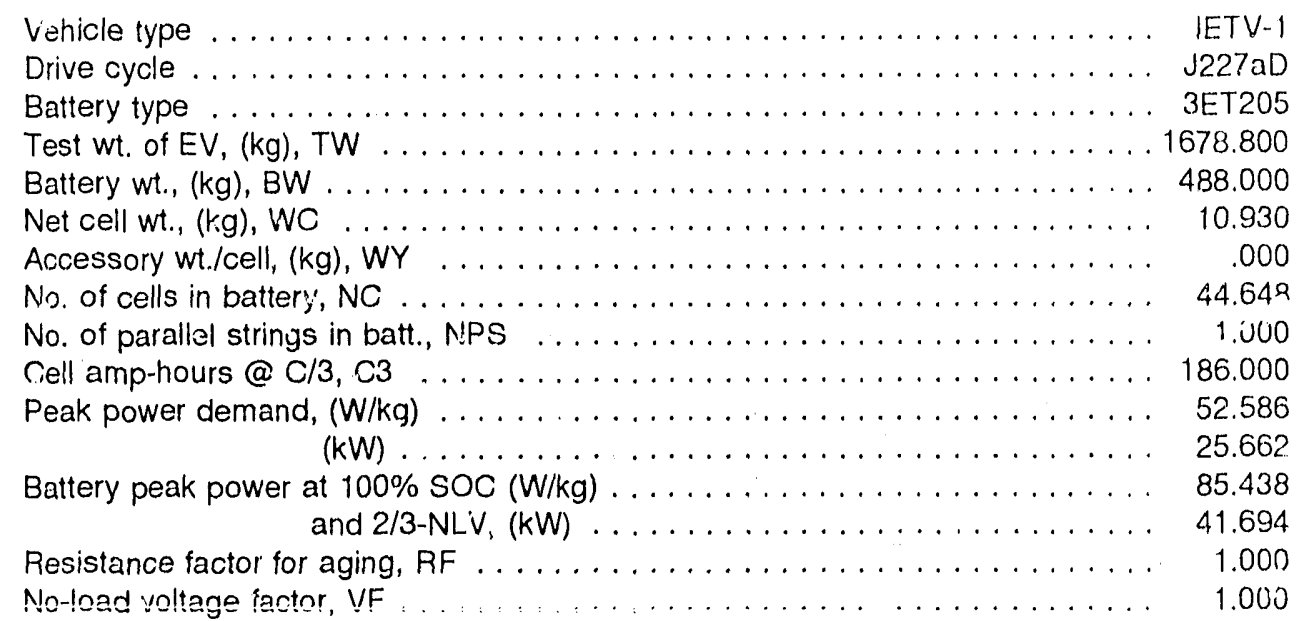


- To temporarily halt display on the screen, simultaneously press the Ctrl and $\mathrm{S}$ keys; press any key to resume.

- To interrupt computation and terminate program execution, simultancously press the Ctrl and Break keys.

9. Calculational results similar to the following will be displayed on the screen at the conclusion of a case:

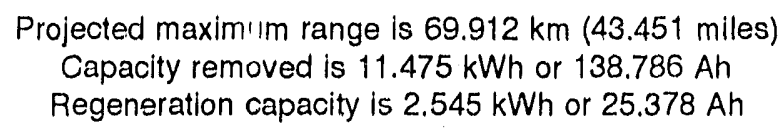

10. If you are using the version with graphics capability (DIANE2.1.EXE), the program will ask if you want to see the profile-by-profile data (maximum current as well as minimum voltage in each driving profile) plotted. If you enter $y$, the following plotting menu will appear on the screen, which allows you to select the desired plot:

0: No plotting; return
1: Maximum cell current vs. driving profile \#
2: Maximum battery current vs. range $(\mathrm{km})$
3: Maximum battery current vs. time $(\mathrm{h})$
4: Minimum cell voltage vs. driving profile \#
5: Minimum battery voltage vs. range $(\mathrm{km})$
6: Minimum battery voltage vs. time $(\mathrm{h})$

11. If IACC $=1$, vehicle speed (up to $80 \mathrm{mph}$ ) and distance iravelled as a function of time will be computed for the hypothetical case of maximum-power acceleration. No degradation of battery power capability due to depth-of-discharge effect is considered for the calculation.

12. Upon completion of a run, you will be asked if you want to run another case for the same combination of vehicle, driving profile, and battery system. If you enter $y$ (for yes), the interactive screen display shown in Step 7 will reappear, which allows you to change the values of the parameters before another run is made. You can also change the output device and title at this time.

13. If you do not want to make another run for the same system, press any key. You will then be asked if you want to choose another system for study. If you enter y, the program will go to Step 3 to let you select an output device and a new combination (vehicle, driving profile, battcry technology) for study. 


\subsection{Sample Problems}

To demonstrate the use of DIANE 2.1, three sample problems (listed in Table 3.1), are included in the software package. Appendix E shows the output of the sample problems.

TABLE 3.1 Sample Problems

File Name System Studied

SAMPLE-1 IETV-1/J227aD/3ET205

SAMPLE-2 Same as SAMPLE-1, except power profile is input

SAMPLE-3 Same as SAMPLE-1, except RF $=1.1, I P I N=0$, and $\mid A C C=0$ 


\section{$15 / 16$}

\section{References}

DcLuca, W.H., et al., 1989, Laboratory Evaluation of Advanced Battery Technologies for Electric Vehicle Applications, International Congress and Exposition, Socicty of Automotive Enginecrs (SAE) Publication No. 890820, Detroit, Mich., Feb. 27-March 3.

DOE, 1988, EHP Battery Test Working Task Force, A Simplified Version of the Federal Urban Driving Schedule for Electric Vehicle Battery Testing, U.S. Department of Energy Report DOE/ID-10146, Aug.

Hcwitt, R., and J. Bryant, 1982, Testing of the Eagle-Picher Nickel-Iron, the Globe ISOA LeadAcid, and the Westinghouse Nickel-Iron Battery Subsystems in an Electric-Vehicle Environment, Jet Propulsion Laboratory, Pasadena, Calif., DOE/CS-54209-10, July 15.

Marr, W.W., and W.J. Walsh, 1984, A Computerized System for Establishing Electric Vehicle Battery Requirements, Proc. 195th Intersocicty Energy Conversion Enginecring Conf. (IECEC), San Francisco, Calif., Aug. 19-24.

Marr, W.W., W.J. Walsh, and P.C. Symons, 1987, User's Guide to DIANE: A Microcomputer Program for Modeling Battery Performance in Electric Vehicles, Argonne National Laboratory Report ANL/CNSV-TM-190, Sept.

Miller, J.F., 1989, unpublished information, Argonne National Laboratory, Argonne, Ill.

Slusscr, R.A., C.P. Chapman, and S.L. Chazanoff, 1982, Electric/Hybrid Vehicle Simulation Program (ELVEC 7.3) User's Manual, Jet Propulsion Laboratory Publication JPL 5030-204, Rev. F, May. 


\section{Appendix A: \\ Calculation of Power Requirement}




\section{Appendix A: Calculation of Power Requirement}

Power requirement at the battery terminals can be calculated from a specificd velocity profile, provided that the vehicle characteristics (test weight, frontal area, drag coefficient, rolling resistance coefficients, the drivetrain efficiency, and the grade of the road) are given.

The instantancous road-load power is calculated from the required force, which overcomes the drag force, the rolling resistance, and the grading effects while, at the same time, maintaining the vehicle at the specified speed. The equations for velocity, force, and power are given below.

The instantaneous speed of the vehicle at time $t$ in any linear driving period can be cxpressed as:

$$
\mathrm{V}=\mathrm{V}_{1}+\mathrm{a} \Delta \mathrm{t}
$$

where:

$$
\begin{aligned}
a & =\text { acceleration or decelcration } \\
& =\left(V_{2}-V_{1}\right) /\left(t_{2}-t_{1}\right) ; \\
V_{1}, V_{2} & =t \text { the sipced at time } t_{1} \text { and } t_{2}, \text { respectively; } \\
\Delta t & =t-t_{1} ; \\
t & =\text { time; } \\
t_{1} & =\text { the time at the beginning of the period; and } \\
t_{2} & =\text { the time at the cnd of the period. }
\end{aligned}
$$

The distance at time $t$ is given by:

$$
S=S_{1}+v_{1} \Delta t+\frac{a}{2}(\Delta t)^{2}
$$

where $S_{1}$ is the distance at time $t_{1}$.

As shown in Fig. A.1, the total required driving force, $F_{1}$, is given by:

$$
\mathrm{F}_{\mathrm{T}}=\mathrm{F}_{\mathrm{D}}+\mathrm{F}_{\mathrm{R}}+\mathrm{F}_{\mathrm{G}}+\mathrm{F}_{\mathrm{A}}
$$

with the air-drag force,

$$
\mathrm{F}_{\mathrm{b}}=\frac{1}{2} \rho \mathrm{C}_{\mathrm{D}} \mathrm{A}_{\mathrm{v}} \mathrm{V}^{2}
$$

the rolling resistance force,

$$
F_{k}=W_{T} \cos \theta\left(K_{0}+K_{1} V+K_{2} V^{2}\right)
$$


the force due to grade,

and the acceleration force,

$$
\mathrm{F}_{\mathrm{g}}=\mathrm{W}_{\mathrm{T}} \sin \theta
$$

$$
F_{\Lambda}=\frac{W_{T}}{g} a
$$

where:

$$
\begin{aligned}
\mathrm{W}_{\mathrm{T}} & =\text { vehicle weight; } \\
\mathrm{g} & =\text { gravitational acceleration; } \\
\theta & =\text { grading angle, } \tan ^{-1}(\% \text { grade } / 100) \\
\mathrm{K}_{0}, \mathrm{~K}_{1}, \mathrm{~K}_{2} & =\text { rolling resistance coefficients; } \\
\mathrm{A}_{\mathrm{F}} & =\text { vehicle frontal area; } \\
\rho & =\text { air density; and } \\
\mathrm{C}_{\mathrm{D}} & =\text { drag coefficient. }
\end{aligned}
$$

The power at the wheels,$P_{w h}$, is given by:

$$
\mathrm{P}_{\mathrm{wh}}=\mathrm{VF}_{\mathrm{T}}
$$

and the power required at the battery terminals is:

$$
P_{B}=\frac{P_{w h}}{\eta_{D} \eta_{M}}
$$

where $\eta_{D}$ and $\eta_{M}$ are efficiencies of the transmission and the motor, respectively.

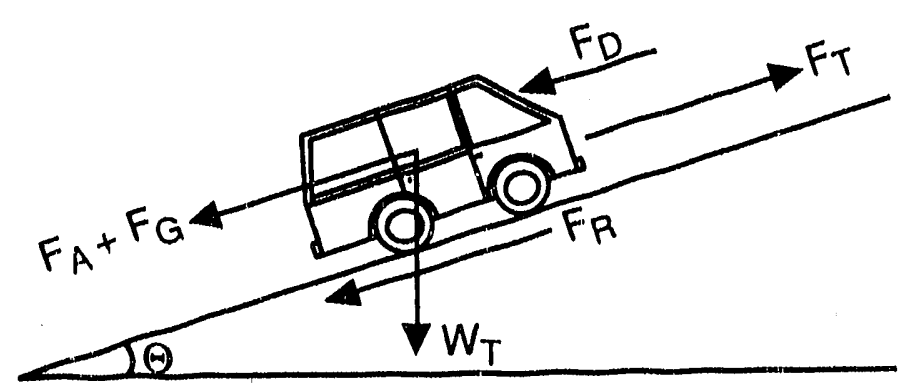

FIGURE A.1 Schematic Diagram of Forces Acting on a Vehicle 
$21 / 22$

Appendix B:

Default Vehicle Data Files 
TABLE B.1 Default Vehicle Data Set for the Eaton Dual-Shaft Electric Propulsion Van (DSEP)

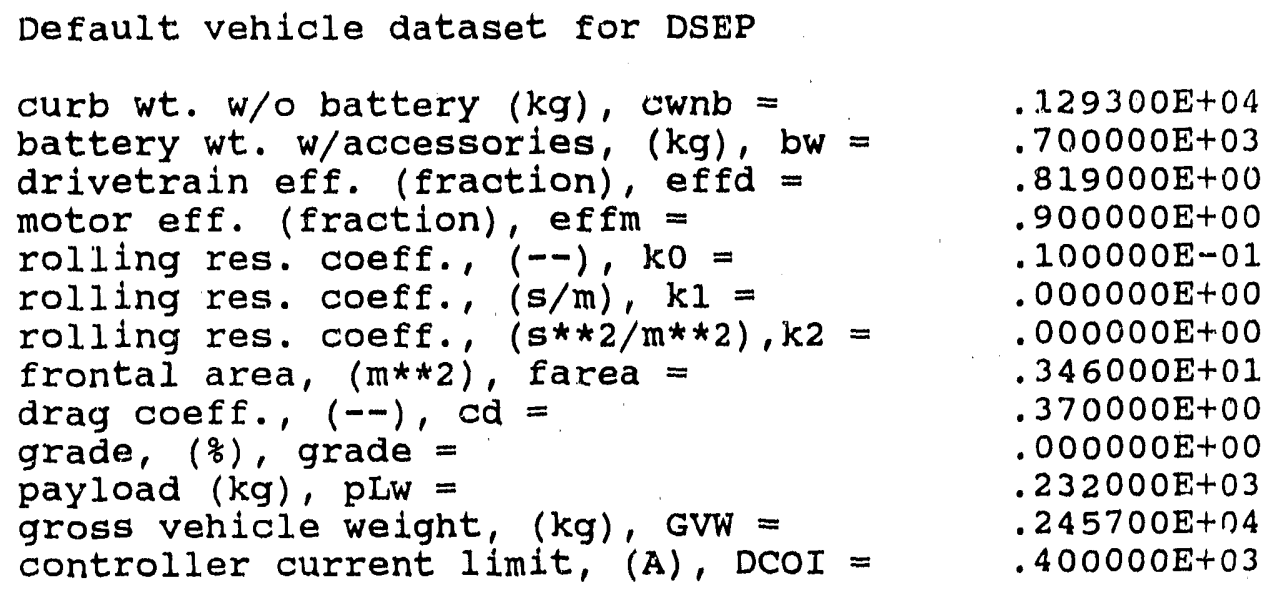

TABLE B.2 Default Vehicle Data Set for the Improved Dual-Shaft Electric Propulsion Van (IDSEP)

Default vehicle dataset for IDSEP

curb wt. $w / 0$ battery (kg), $c w n b=$ battery wt. w/accessories, $(\mathrm{kg}), \mathrm{bw}=.695000 \mathrm{E}+03$ drivetrain eff. (fraction), effd $=\quad .752600 \mathrm{E}+00$ motor eff. (fraction), effm $=\quad .900000 \mathrm{E}+00$ rolling res. coeff., (--), $\mathrm{kO}=\quad .800000 \mathrm{E}-02$ rolling res. coeff., $(\mathrm{s} / \mathrm{m}), \mathrm{kl}=\quad .000000 \mathrm{E}+00$ rolling res. coeff., $(s * * 2 / m * * 2), k 2=.000000 E+00$ frontal area, $(m * * 2)$, farea $=\quad .297000 \mathrm{E}+01$ drag coeff., $(--), c d=\quad .370000 E+00$ grade, $(q)$, grade $=\quad .000000 \mathrm{E}+00$ payload $(\mathrm{kg}), \mathrm{pLw}=\quad .273000 \mathrm{E}+03$ gross vehicle weight, $(\mathrm{kg}), \mathrm{GVW}=\quad .267000 \mathrm{E}+04$ controller current limit, (A), DCOI $=.600000 \mathrm{E}+04$ 
TABLE B.3 Default Vehicle Data Set for the Griffon Electric Van

Default vehicle dataset for Griffon

curb wt. $w / 0$ battery $(\mathrm{kg}), \mathrm{cwnb}=$ $.150200 \mathrm{E}+04$ battery wt. w/accessories, $(\mathrm{kg}), \mathrm{bw}=.113600 \mathrm{E}+04$ drivetrain eff. (fraction), effd $=\quad .750000 E+00$ motor eff. (fraction), effm = rolling res. coeff., (--), $\mathrm{k}_{0}=$ $.900000 E+00$

rolling res. coeff., $(\mathrm{s} / \mathrm{m}), \mathrm{kI}=$ $.830000 \mathrm{E}-02$

rolling res. coeff., $(s * * 2 / m * * 2), k 2=$ $.000000 \mathrm{E}+00$ frontal area, $(m * * 2)$, farea $=$ drag coeff., $(--), c d=$ grade, $(\%)$, grade $=$ payload $(\mathrm{kg}), \mathrm{pLw}=$ gross vehicle weight, $(\mathrm{kg}), \mathrm{GVW}=$ $.000000 \mathrm{E}+00$ $.246000 E+01$ $.370 C 00 E+00$ $.000000 \mathrm{E}+00$ controller current limit, (A), DCOI $=.300000 \mathrm{E}+03$

TABLE B.4 Default Vehicle Data Set for the Second-Generation Single-Shaft Electric Propulsion System (ETX-II)

Default vehicle dataset for ETX-II

curb wt. $w / 0$ battery $(\mathrm{kg}), \mathrm{cwnb}=$ battery wt. w/accessories, $(\mathrm{kg}), \mathrm{bw}=.500000 \mathrm{E}+03$ drivetrain eff. (fraction), effd $=\quad .819000 \mathrm{E}+00$ motor eff. (fraction), effm = rolling res. coeff., (--), $\mathrm{k} 0=$ rolling res. coeff., $(\mathrm{s} / \mathrm{m}), \mathrm{kl}=$ rolling res. coeff., $(s * * 2 / m * * 2), k 2=$ frontal area, $(m * * 2)$, farea $=$ drag coeff., $(--), \mathrm{cd}=$ grade, $(\%)$, grade $=$ payload $(\mathrm{kg}), \mathrm{pLw}=$ gross vehicle weight, $(\mathrm{kg}), \mathrm{GVw}=$ $.900000 E+00$ $.100000 E-01$ $.000000 E+00$ $.000000 \mathrm{E}+00$ $.295000 E+01$ $.370000 E+00$ $.000000 \mathrm{E}+00$ $.258000 \mathrm{E}+03$ controller current limit, $(A)$, DCOI $=\quad .480000 E+03$ 
TABLE B.5 Default Vehicle Data Set for the G-Van

Default Vehicle Datafile for G-VAN

curb wt. w/o batt. (kg), cwnb =

$.200900 \mathrm{E}+04$

battery wt. w/accessories, (kg), bw=

$.115500 \mathrm{E}+04$

drivetrain eff. (fraction), effd = motor eff. (fraction), effm =

$.794000 \mathrm{E}+00$

$.900000 \mathrm{E}+00$

rolling res. coeff., (--), $\mathrm{k} 0=$

rolling res. coeff., $(\mathrm{s} / \mathrm{m}), \mathrm{k} 1=$

$.100000 \mathrm{E}-01$

rolling res. coeff., $(s * \star 2 / m * \star 2), k 2=$

$.000000 \mathrm{E}+00$

frontal area, $(m * * 2)$, farea $=$

$.000000 \mathrm{E}+00$

drag coeff., $(--)$, cd =

grade, $(\%)$, grade $=$

payload $(\mathrm{kg}), \mathrm{pLw}=$

gross vehicle weight, $(\mathrm{kg}), \mathrm{GVW}=$

$437000 E+01$

$.370000 E+00$

$.000000 \mathrm{E}+00$

$.409000 \mathrm{E}+03$

$.398200 \mathrm{E}+04$

controller current limit, (A), DCOI =

$.300000 \mathrm{E}+03$

TABLE B.6 Default Vehicle Data Set for the TEVan

Default vehicle dataset for TEVan

clirb wt. $w / 0$ battery $(\mathrm{kg}), \mathrm{cwnb}=$ battery wt. w/accessories, (kg), bw = drivetrain eff. (fraction), effd = motor eff. (fraction), effm = rolling res. coeff., $(--), \mathrm{kO}_{0}=$ rolling res. coeff., $(\mathrm{s} / \mathrm{m}), \mathrm{kl}=$ rolling res. coeff., $(s * \star 2 / m * * 2), k 2=$ frontal area, $(m * \star 2)$, farea $=$ drag coeff., $(--), \mathrm{cd}=$ grade, $(\%)$, grade $=$ payload (kg), pLw = gross vehicle weight, $(\mathrm{kg}), \mathrm{GVW}=$ controller current limit, (A), DCOI =

$.124600 E+04$ $.700000 E+03$ $.950000 \mathrm{E}+00$ $.900000 \mathrm{E}+00$ $.830000 E-02$ $.000000 \mathrm{E}+00$ $.000000 \mathrm{E}+00$ $.246000 \mathrm{E}+01$ $.370000 \mathrm{E}+00$ $.000000 \mathrm{E}+00$ $.273000 E+03$ $.249200 \mathrm{E}+04$ $.300000 E+03$ 
TABLE B.7 Default Vehicle Data Set for the Improved Electric Test Vehicle (IETV-1)

Default vehicle dataset for IETV-1

curb wt. $w / 0$ battery $(\mathrm{kg}), \mathrm{cwnb}=$

battery wt. w/accessories, (kg), bw = $.103200 \mathrm{E}+04$ drivetrain eff. (fraction), effd = motor eff. (fraction), effm = rolling res. coeff., $(--), k 0=$ rolling res. coeff., $(\mathrm{s} / \mathrm{m}), \mathrm{kl}=$ rolling res. coeff., $(s * * 2 / m * * 2), k 2=$ frontal area, $(m * \star 2)$, farea $=$ drag coeff., $(--), c d=$ grade, $(z)$, grade $=$ payload $(\mathrm{kg}), \mathrm{pLw}=$ gross vehicle weight, $(\mathrm{kg}), \mathrm{GVw}=$ controller current limit, (A), DCOI =

$.488000 \mathrm{E}+03$

$.870000 \mathrm{E}+0 \mathrm{n}$

$.900000 \mathrm{E}+00$

$.900000 \mathrm{E}-02$

$.000000 \mathrm{E}+00$

$.000000 \mathrm{E}+00$

$.174000 \mathrm{E}+01$

$.310000 \mathrm{E}+00$

$.000000 \mathrm{E}+00$

$.158800 \mathrm{E}+03$

$.183760 \mathrm{E}+04$

$.600000 E+03$

TABLE B.8 Default Vehicle Data Set for the Impact

Default Vehicle Data File for IMPACT curb wt. w/o batt. $(\mathrm{kg}), \mathrm{cwnb}=$

$.603000 E+03$ battery wt. w/accessories, $(\mathrm{kg}), \mathrm{bw}=$ drivetrain eff. (fraction), effd = motor eff. (fraction), effm = rolling res. coeff., (--), k.0 = rolling res. coeff., $(\mathrm{s} / \mathrm{m}), \mathrm{kl}=$ rolling res. coeff., $(s * \star 2 / m * * 2), k 2=$ frontal area, $(m * * 2)$, farea $=$ drag coeff., (--), cd = grade, $(q)$, grade $=$ payload $(\mathrm{kg}), \mathrm{pLw}=$ gross vehicle weight, $(\mathrm{kg}), \mathrm{GVW}=$ $.397000 \mathrm{E}+03$

$.840000 \mathrm{E}+00$

$.900000 \mathrm{E}+00$

$.480000 E-02$

$.000000 E+00$

$.000000 \mathrm{E}+00$

$.290000 \mathrm{E}+01$

$.190000 \mathrm{E}+00$

$.000000 \mathrm{E}+00$

$.780000 \mathrm{E}+02$

$.115650 E+04$ controller current limit, (A), DCOI =

$.300000 E+03$ 
Appendix C:

\section{Default Driving Profile Data Files}


TABLE C.1 Driving Profile for SAE J227aC (JPL-Standardized)

SAE J227AC (JPL-Standardized) DRIVING PROFILE cycle time including rest, (s), TC= rest time at end of cycle, (s), TREST = $\mathrm{s}$-by-s velocity, $(\mathrm{km} / \mathrm{h})$, for TC-TREST $\mathrm{s}$
$.426000 \mathrm{E}+01$ $.854000 \mathrm{E}+01$
$.245900 \mathrm{E}+02$
$.278800 \mathrm{E}+02$
$.383400 \mathrm{E}+02$
$.403500 \mathrm{E}+02$
$.128200 \mathrm{E}+02$
$.308600 E+02$
$.463700 \mathrm{E}+02$
$.473900 \mathrm{E}+02$
$.482700 \mathrm{E}+02$
$.421700 \mathrm{E}+02$
$.482700 \mathrm{E}+02$
$.482700 \mathrm{E}+02$
$.482700 \mathrm{E}+02$
$.482700 \mathrm{E}+02$
$.482700 \mathrm{E}+02$
$.482700 \mathrm{E}+02$
$.482700 \mathrm{E}+02$
$.482700 \mathrm{E}+02$
. $48 \angle 700 E+02$
$.482700 \mathrm{E}+02$
$.482700 E+02$
$.448800 \mathrm{E}+02$
$.440900 \mathrm{E}+02$
$.433600 \mathrm{E}+02$
$.371800 \mathrm{E}+02$
$.325300 \mathrm{E}+02$
$.139500 \mathrm{E}+02$
$.930000 \mathrm{E}+01$

80

25

$.170600 \mathrm{E}+02$

$.336100 E+02$

$.437600 E+02$

$.482700 \mathrm{E}+02$

$.482700 \mathrm{E}+02$

$.482700 \mathrm{E}+02$

$.482700 \mathrm{E}+02$

$.469700 \mathrm{E}+02$

$.427800 \mathrm{E}+02$

$.278800 \mathrm{E}+02$

$.465000 \mathrm{E}+01$
$.210000 \mathrm{E}+02$ . $360900 \mathrm{E}+02$ $.451600 \mathrm{E}+02$ $.482700 \mathrm{E}+02$ $.482700 \mathrm{E}+02$ $.482700 \mathrm{E}+02$ $.482700 \mathrm{E}+02$ $.458900 \mathrm{E}+02$ $.422700 \mathrm{E}+02$ $.232300 \mathrm{E}+02$ $.000000 \mathrm{E}+00$

TABLE C.2 Driving Profile for SAE J227aD (JPL Standardized)

SAE J227AD (JPL-Standardized) DRIVING PROFILE cycle time including rest, (s), TC= rest time at end of cycle, (s), TREST = s-by-s velocity, $(\mathrm{km} / \mathrm{h})$, for TC-TREST $\mathbf{s}$
$.412000 \mathrm{E}+01$
$.824000 \mathrm{E}+01$
$.247100 \mathrm{E}+02$
$.286200 \mathrm{E}+02$
$.421600 \mathrm{E}+02$
$.450700 \mathrm{E}+02$
$.551400 \mathrm{E}+02$
$.572800 \mathrm{E}+02$
$.644900 \mathrm{E}+02$
$.659700 \mathrm{E}+02$
$.706800 \mathrm{E}+02$
$.715800 \mathrm{E}+02$
$.724000 \mathrm{E}+02$
$.724000 \mathrm{E}+02$
$.724000 \mathrm{E}+02$
$.724000 \mathrm{E}+02$
$.724000 \mathrm{E}+02$
$.724000 \mathrm{E}+02$
$.724000 \mathrm{E}+02$
$.724000 \mathrm{E}+02$
$.724000 \mathrm{E}+02$
$.724000 E+02$
$.724000 E+02$
$.724000 \mathrm{E}+02$
$.724000 \mathrm{E}+02$
$.724000 \mathrm{E}+02$
$.724000 \mathrm{E}+02$
$.724000 \mathrm{E}+02$
$.665000 \mathrm{E}+02$
$.560400 \mathrm{E}+02$
$.305700 \mathrm{E}+02$
$.724000 \mathrm{E}+02$
$.724000 \mathrm{E}+02$
$.724000 E+02$
$.724000 \mathrm{E}+02$
$.650000 E+02$
$.509600 \mathrm{E}+02$
$.254700 \mathrm{E}+02$
$.123600 \mathrm{E}+02$
$.323100 \mathrm{E}+02$
$.478200 \mathrm{E}+02$
$.592900 \mathrm{E}+02$
$.673400 \mathrm{E}+02$
$.724000 \mathrm{E}+02$
$.724000 \mathrm{E}+02$
$.724000 \mathrm{E}+02$
$.724000 \mathrm{E}+02$
$.724000 E+02$
$.724000 E+02$
$.724000 \mathrm{E}+02$
$.724000 \mathrm{E}+02$
$.724000 \mathrm{E}+02$
$.724000 \mathrm{E}+02$
$.724000 \mathrm{E}+02$
$.636000 \mathrm{E}+02$
$.458600 \mathrm{E}+02$
$.203900 E+02$

122

25

$.164800 \mathrm{E}+02$

$.357800 \mathrm{E}+02$

$.504300 \mathrm{E}+02$

$.611600 \mathrm{E}+02$

$.685600 \mathrm{E}+02$

$.724000 \mathrm{E}+02$

$.724000 \mathrm{E}+02$

$.724000 \mathrm{E}+02$

$.724000 \mathrm{E}+02$

$.724000 \mathrm{E}+02$

$.724000 \mathrm{E}+02$

$.724000 \mathrm{E}+02$

$.724000 \mathrm{E}+02$

$.724000 \mathrm{E}+02$

$.724000 E+02$

$.700400 E+02$

$.623200 \mathrm{E}+02$

$.407600 \mathrm{E}+02$

$.152900 \mathrm{E}+02$
$.206000 E+02$ $.390700 \mathrm{E}+02$

$.528600 \mathrm{E}+\mathrm{O} 2$

. $629000 \mathrm{E}+02$

$.696900 \mathrm{E}+02$

$.724000 E+02$

$.724000 \mathrm{E}+02$

$.724000 \mathrm{E}+02$

$.724000 \mathrm{E}+02$

$.724000 \mathrm{E}+02$

$.724000 \mathrm{E}+02$

$.724000 \mathrm{E}+02$

$.724000 \mathrm{E}+02$

$.724000 \mathrm{E}+02$

$.724000 \mathrm{E}+02$

$.681100 \mathrm{E}+02$

$.611400 \mathrm{E}+02$

$.356700 \mathrm{E}+02$

$.101800 \mathrm{E}+02$ 
TABLE C.3 Simplified Federal Urban Driving Schedule (SFUDS), Velocity Slightly Changed Simplified FUDS (SFUDS) with velocity slightly changed
cycle time including rest, (s), TC= rest time at end of cycle, (s), TREST = s-by-s velocity, $(\mathrm{km} / \mathrm{h})$, for TC-TREST $s$

$.000000 \mathrm{E}+00$

$.000000 \mathrm{E}+00$

$.000000 E+00$

$.000000 \mathrm{E}+00$

$.111000 \mathrm{E}+02$

$.169000 \mathrm{E}+02$

$.208000 \mathrm{E}+02$

$.240000 \mathrm{E}+02$

$.275000 \mathrm{E}+02$

$.340000 \mathrm{E}+02$

. $388000 \mathrm{E}+02$

$.320000 E+02$

$.171000 \mathrm{E}+02$

$.00000 C E+00$

$.000000 E+00$

$.000000 \mathrm{E}+00$

$.111000 \mathrm{E}+02$

$.169000 \mathrm{E}+02$

$.208000 \mathrm{E}+02$

. $240000 E+02$

$.275000 \mathrm{E}+\mathrm{C} 2$

$.340000 \mathrm{E}+02$

$.388000 \mathrm{E} r \mathrm{O} 2$

$.320000 \mathrm{E}+02$

$.171000 \mathrm{E}+02$

$.000000 \mathrm{E}+0 \mathrm{O}$

$.000000 \mathrm{E}+00$

$.000000 \mathrm{E}+00$

$.111000 \mathrm{E}+02$

$.169000 \mathrm{E}+02$

$.208000 \mathrm{E}+02$

$.240000 \mathrm{E}+02$

$.275000 E+02$

$.340000 E+02$

$.388000 \mathrm{E}+02$

$.320000 E+02$

$.171000 \mathrm{E}+02$

$.000000 E+00$

$.000000 \mathrm{E}+00$

$.000000 E+00$

$.111000 \mathrm{E}+02$

$.169000 \mathrm{E}+02$

$.208000 \mathrm{E}+02$

$.240000 E+02$
$.000000 \mathrm{E}+00$

$.000000 \mathrm{E}+00$

$.000000 \mathrm{E}+00$

$.240000 \mathrm{E}+01$

$.122000 \mathrm{E}+02$

$.179000 \mathrm{E}+02$

$.214000 \mathrm{E}+02$

$.245000 \mathrm{E}+02$

$.290000 \mathrm{E}+02$

. $351000 \mathrm{E}+02$

. $396000 \mathrm{E}+02$

. $301000 E+02$

$.114000 \mathrm{E}+02$

$.000000 E+00$

$.000000 E+00$

$.240000 E+01$

$.122000 \mathrm{E}+02$

$.179000 \mathrm{E}+02$

. $214000 \mathrm{E}+02$

. $245000 \mathrm{E}+02$

$.290000 \mathrm{E}+02$

. $351000 \mathrm{E}+02$

. $396000 \mathrm{E}+02$

$.301000 E+02$

$.114000 \mathrm{E}+02$

$.000000 \mathrm{E}+00$

$.000000 E+00$

$.240000 \mathrm{E}+01$

$.122000 \mathrm{E}+02$

$.179000 \mathrm{E}+02$

$.214000 \mathrm{E}+02$

. $245000 \mathrm{E}+02$

$.290000 \mathrm{E}+02$

. $351000 \mathrm{E}+02$

. $396000 \mathrm{E}+02$

. $301000 \mathrm{E}+02$

$.114000 \mathrm{E}+02$

$.000000 \mathrm{E}+00$

$.000000 E+00$

$.240000 E+01$

$.122000 \mathrm{E}+02$

$.179000 \mathrm{E}+02$

$.214000 \mathrm{E}+02$

$.245000 E+02$
$.000000 \mathrm{E}+00$

$.000000 \mathrm{E}+00$

$.000000 \mathrm{E}+00$

$.480000 \mathrm{E}+01$

$.134000 \mathrm{E}+02$

$.187000 \mathrm{E}+02$

$.220000 \mathrm{E}+02$

$.24900 \mathrm{DE}+02$

$.303000 E+02$

$.360000 \mathrm{E}+02$

$.378000 \mathrm{E}+02$

$.277000 \mathrm{E}+02$

$.580000 \mathrm{E}+01$

$.000000 E+00$

$.000000 \mathrm{E}+00$

$.480000 E+01$

$.134000 \mathrm{E}+\mathrm{C} 2$

$.187000 \mathrm{E}+02$

$.220000 \mathrm{E}+02$

$.249000 \mathrm{E}+02$

$.303000 \mathrm{E}+02$

$.360000 \mathrm{E}+02$

$.378000 \mathrm{E}+02$

$.277000 \mathrm{E}+02$

$.580000 \mathrm{E}+01$

$.000000 \mathrm{E}+00$

$.000000 \mathrm{E}+00$

$.480000 \mathrm{E}+01$

$.134000 \mathrm{E}+02$

$.187000 \mathrm{E}+02$

$.220000 E+02$

$.249000 \mathrm{E}+02$

$.303000 \mathrm{E}+02$

$.360000 \mathrm{E}+02$

$.378000 \mathrm{E}+02$

$.277000 \mathrm{E}+02$

$.580000 \mathrm{E}+01$

$.000000 \mathrm{E}+00$

$.000000 E+00$

$.480000 E+01$

$.134000 \mathrm{E}+02$

$.187000 \mathrm{E}+02$

$.220000 \mathrm{E}+02$

$.249000 \mathrm{E}+02$
$.000000 E+00$

$.000000 \mathrm{E}+00$

$.000000 E+00$

$.720000 E \div 01$

$.146005 \mathrm{E}+02$

$.195000 \mathrm{E}+02$

$.227000 E+02$

.25600UE+02

. $315000 \mathrm{E}+02$

$.37000 \mathrm{CE}+02$

$.359000 E+C 2$

$.253000 E+02$

$.200000 \mathrm{E}+00$

$.000000 \mathrm{E}+00$

$.000000 \mathrm{E}+00$

$.720000 \mathrm{~F}+01$

$.146000 \mathrm{E}+02$

$.195000 \mathrm{E}+02$

$.227000 \mathrm{E}+02$

$.256000 \mathrm{E}+02$

$.315000 \mathrm{E}+02$

$.370000 \mathrm{E}+02$

$.359000 \mathrm{E}+02$

$.253000 \mathrm{E}+02$

$.200000 \mathrm{E}+00$

$.000000 \mathrm{E}+00$

$.000000 E+00$

$.720000 E+01$

$.146000 \mathrm{E}+02$

$.195000 \mathrm{E}+02$

$.256000 \mathrm{E}+02$

$.315000 \mathrm{E}+02$

$.370000 \mathrm{E}+02$

$.359000 E+02$

$.253000 E+02$

$.200000 E+00$

$.000000 E+00$

$.000000 E+00$

$.72000 \mathrm{CE}+01$

$.146000 \mathrm{E}+02$

$.195000 \mathrm{E}+02$

$.227000 \mathrm{E}+02$

$.256000 \mathrm{E}+02$
$.227000 E+02$
$.000000 \mathrm{E}+00$

$.000000 \mathrm{E}+00$

$.000000 E+00$

$.970000 \mathrm{E}+01$

$.158000 \mathrm{E}+02$

$.201000 \mathrm{E}+02$

$.233000 \mathrm{E}+02$

$.261 .000 \mathrm{E}+02$

$.328000 \mathrm{E}+02$

$.378000 \mathrm{E}+02$

$.341000 \mathrm{E}+02$

$.227000 \mathrm{E}+02$

$.000000 E+00$

$.000000 E+00$

$.000000 E+00$

$.970000 E+01$

$.158000 \mathrm{E}+\mathrm{n} 2$

$.201000 \mathrm{E}+02$

$.233000 E+02$

$.261000 \mathrm{E}+02$

$.3280 \cup 0 \mathrm{E}+\mathrm{U} 2$

$.378000 \mathrm{E}+02$

. $341000 \mathrm{E}+02$

$.227000 \mathrm{E}+02$

$.000000 E+00$

$.000000 E+00$

$.000000 \mathrm{E}+00$

$.970000 E+01$

$.158000 \mathrm{E}+02$

$.201000 \mathrm{E}+02$

$.23300 \mathrm{CE}+02$

$.261000 \mathrm{E}+02$

$228000 \mathrm{E}+\mathrm{C} 2$

$.378000 \mathrm{E}+02$

$.341000 \mathrm{E}+02$

$22 \% 000 \mathrm{E}+02$

$.000000 \mathrm{E}+00$

$.000000 E+00$

$.000000 E+00$

$.970000 E+01$

$.158000 \mathrm{E}+02$

$.201000 \mathrm{E}+02$

$.233000 \mathrm{E}+02$

$.261000 \mathrm{E}+02$ 
TABLE C.3 (Cont'd)

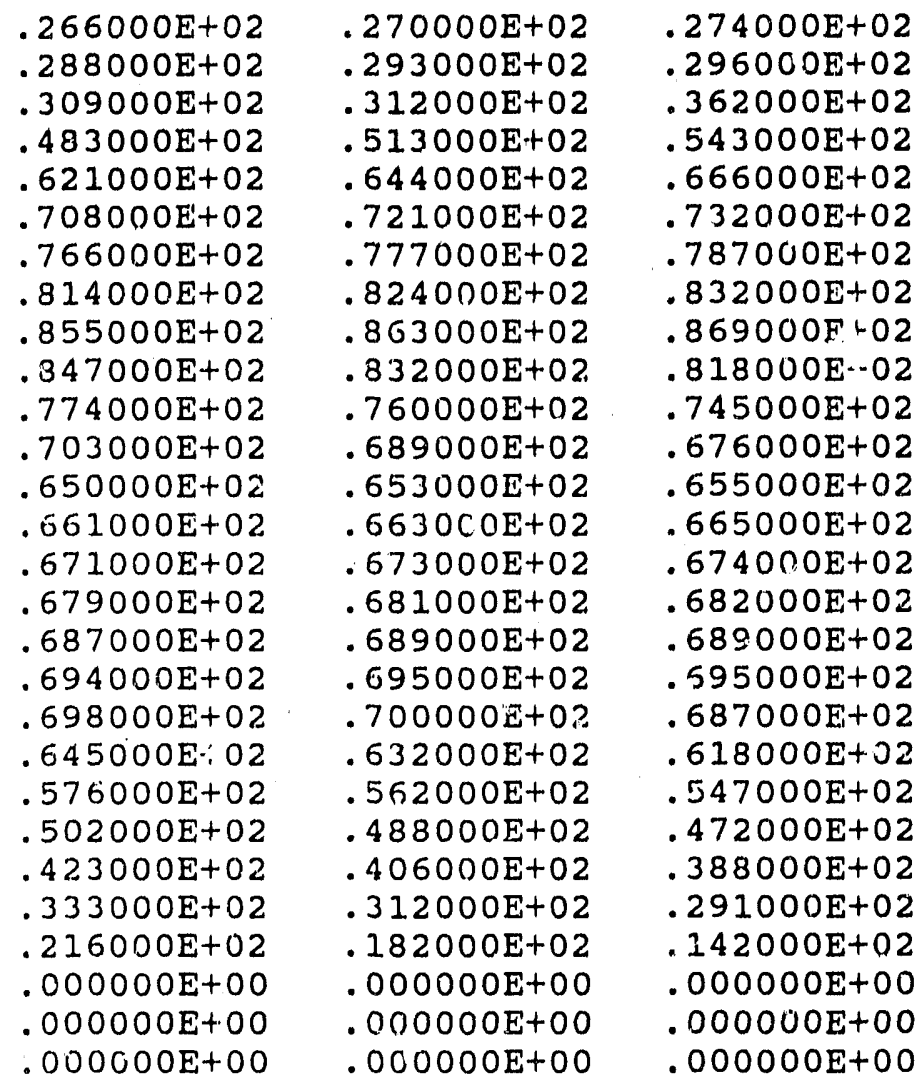

$.270000 \mathrm{E}+02$ .

.

$.721000 \mathrm{E}+02$

$.777000 \mathrm{E}+02$

$.824000 \mathrm{E}+02$

. $863000 \mathrm{E}+02$

$760000 \mathrm{Et}$

$.689000 \mathrm{E}+02$

$653000 \mathrm{E}+02$

$6630 \mathrm{COE}+02$

$681000 \mathrm{E}+02$

$.689000 \mathrm{E}+02$

$.695000 \mathrm{E}+02$

. $562000 \mathrm{E}+02$

$.488000 \mathrm{E}+02$

$406000 \mathrm{E}+02$

$182000 \mathrm{E}+02$

$.000000 \mathrm{E}+00$

$.000000 \mathrm{E}+00$
$.278000 \mathrm{E}+02$ $.301000 \mathrm{E}+02$

$.407000 \mathrm{E}+02$ $.571000 \mathrm{E}+02$

$.68100 \mathrm{Uk}+02$

$.744000 \mathrm{E}+02$

$.797000 \mathrm{E}+02$ $.840000 \mathrm{E}+02$ $.875000 \mathrm{E}+02$ $.803000 \mathrm{E}+02$

$.731000 \mathrm{E}+02$ $.663000 \mathrm{E}+02$ $.657000 \mathrm{E}+02$ $.668000 \mathrm{E}+02$ $.676000 \mathrm{E}+02$ $.684000 \mathrm{E}+02$ $.690000 \mathrm{E}+02$ $.697000 \mathrm{E}+02$ $.673000 \mathrm{E}+02$ $.604000 E+02$ $.533000 \mathrm{E}+02$ $.457000 \mathrm{E}+02$ $.370000 \mathrm{E}+02$ $.267000 \mathrm{E}+02$ $.930000 E+01$ $.000000 \mathrm{E}+00$ $.000000 E+00$ $.000000 E+00$
$.283000 \mathrm{E}+02$ $.304000 \mathrm{E}+02$ $.447000 \mathrm{E}+02$ $.597000 \mathrm{E}+02$ $.695000 \mathrm{E}+\mathrm{O} 2$ $.755000 \mathrm{E}+02$ $.806000 \mathrm{E}+02$ $.848000 \mathrm{E} \div 02$ $.861000 \mathrm{E}+02$ $.789000 \mathrm{E}+02$ $.718000 \mathrm{E}+02$ $.649000 \mathrm{E}+02$ $.660000 E+02$ $.669000 \mathrm{E}+02$ $.678000 \mathrm{E}+02$ $.586000 \mathrm{E}+02$ $.692000 \mathrm{E}+02$ $.698000 \mathrm{E}+02$ $.660000 \mathrm{E}+02$ $.591000 \mathrm{E}+\mathrm{C} 2$ $.518000 \mathrm{E}+02$ $.441000 \mathrm{E}+02$ $.352000 \mathrm{E}+02$ $.243000 \mathrm{E}+02$ $.450000 E+01$ $.000000 \mathrm{E}+00$ $.000000 \mathrm{E}+00$ $.000000 \mathrm{E}+00$ 
TABLE C.4 Power Profile (W/kg-batt) at Battery Terminals for J227aD and the Improved Electric Tesl Vehicle (IETV-1/J227aD)

Power profile ( $\mathrm{W} / \mathrm{kg}$ _batt) at battery terminals for IETV-1/J22iaD cycle time including rest (s), TC= rest time at end of cycle (s), TREST = driving distance in a cycle $(\mathrm{km}), \mathrm{RC}=$ s-by-s power,

$.620000 \mathrm{E}+01$ $(w / \mathrm{kg})$, for TC-TREST $\mathrm{s}$

$.373700 E+02$ $.124000 \mathrm{E}+02$ $.186200 \mathrm{E}+02$ $.414600 \mathrm{E}+02$

$.501700 \mathrm{E}+02$ $.511200 \mathrm{E}+02$ $.518800 \mathrm{E}+02$ $.470500 \mathrm{E}+02$ $.514500 \mathrm{E}+02$ $.459200 \mathrm{E}+02$ $.445400 \mathrm{E}+02$ $.518900 \mathrm{E}+02$ $.509300 \mathrm{E}+02$ $.383800 \mathrm{E}+02$ $.153800 \mathrm{E}+02$ $.153800 \mathrm{E}+02$ $.153800 \mathrm{E}+02$ $.153800 \mathrm{E}+02$ $.153800 \mathrm{E}+02$ $.153800 \mathrm{E}+02$ $.153800 \mathrm{E}+02$ $.153800 \mathrm{E}+02$ $.153800 \mathrm{E}+02$ $.153800 \mathrm{E}+02$

$-.142400 E+02$

$-.535000 \mathrm{E}+02$ $.368700 \mathrm{E}+02$ $.153800 \mathrm{E}+02$ $.446100 \mathrm{E}+02$ $.355000 \mathrm{E}+02$ $.153800 \mathrm{E}+02$ $.153800 \mathrm{E}+02$ $.153800 \mathrm{E}+02$ $.153800 E+02$ $.153800 \mathrm{E}+02$ $.153800 \mathrm{E}+02$ $.153800 \mathrm{E}+02$ $.153800 \mathrm{E}+02$ $.153800 E+02$ $.153800 \mathrm{E}+02$ $.153800 \mathrm{E}+02$ $-.125900 \mathrm{E}+02$

$-.487800 \mathrm{E}+02$ $.153800 \mathrm{E}+02$ $.153800 \mathrm{E}+02$ $.153800 \mathrm{E}+02$ $.153800 \mathrm{E}+02$ $.153800 \mathrm{E}+02$ $.153800 \mathrm{E}+02$ $.153800 \mathrm{E}+02$ $.153800 \mathrm{E}+02$ $-.111400 \mathrm{E}+02$

$-.300100 E+02$

$-.504000 E+01$

$-.250900 \mathrm{E}+02$

$-.443700 E+02$

$-.200600 \mathrm{E}+02$ 122 25 $.159000 \mathrm{E}+01$

$.248700 E+02$

$.468300 \mathrm{E}+02$

$.525900 \mathrm{E}+02$

$.499100 \mathrm{E}+02$

$.421600 \mathrm{E}+02$

$.153800 \mathrm{E}+02$

$.153800 \mathrm{E}+02$

$.153800 \mathrm{E}+02$

$.153800 \mathrm{E}+02$

$.153800 \mathrm{E}+02$

$.153800 \mathrm{E}+02$

$.153800 \mathrm{E}+02$

$.153800 \mathrm{E}+02$

$.153800 \mathrm{E}+02$

$.153800 \mathrm{E}+02$

$-.255000 \mathrm{E}+02$

$-.949000 \mathrm{E}+01$

$-.396500 \mathrm{E}+02$

$-.151400 \mathrm{E}+02$
$.311500 \mathrm{E}+02$ $.489500 \mathrm{E}+02$

$.521600 E+02$

$.488300 \mathrm{E}+02$

$.409500 \mathrm{E}+02$

$.153800 \mathrm{E}+02$

$.153800 E+02$

$.153800 \mathrm{E}+02$

$.153800 \mathrm{E}+02$

$.153800 E+02$

$.153800 \mathrm{E}+02$

$.153800 \mathrm{E}+02$

$.153800 \mathrm{E}+02$

$.153800 E+02$

$.153800 \mathrm{E}+02$

$-.189300 \mathrm{E}+02$

$-.815000 \mathrm{E}+01$

-.348000E+02

$-.101200 \mathrm{E}+02$ 
TABLE C.5 Power Proflle at Battery Terminals for the SImplifled Federal Urban Driving Schedule and the Improved Dual-Shaft Electric Propulslon Van (BW=695 kg)

\begin{tabular}{|c|c|c|c|c|}
\hline $\begin{array}{l}\text { cycle time ing } \\
\text { rest time at } \\
\text { driving distar } \\
\text { s-by-s power, }\end{array}$ & $\begin{array}{l}\text { luding rest, } \\
\text { nd of cycle, } \\
\text { ce in a cycle } \\
\text { (w/kg batt), }\end{array}$ & $\begin{array}{l}\text { s), TC= } \\
\text { s): TREST = } \\
\text { (km) RC }= \\
\text { or TC-TREST s }\end{array}$ & $\begin{array}{c}360 \\
0 \\
.310000 \mathrm{E}+01\end{array}$ & \\
\hline $.000000 \mathrm{E}+00$ & $.000000 E+00$ & $.000000 E+00$ & $.000000 E+00$ & $.000000 \mathrm{E}+00$ \\
\hline $.000000 E+00$ & $.000000 \mathrm{E}+00$ & $.000000 \mathrm{E}+00$ & $.000000 E+00$ & $.000000 E+00$ \\
\hline OOE+OO & $0000 \mathrm{E}+00$ & $.000000 E+00$ & $.000000 E+00$ & $.000000 \mathrm{E}+00$ \\
\hline $000 E+00$ & $.100000 E+02$ & $.100000 \mathrm{E}+02$ & $.100000 \mathrm{E}+02$ & $.100000 \mathrm{E}+02$ \\
\hline $.100000 \mathrm{E}+02$ & $100000 E+02$ & $.100000 \mathrm{E}+02$ & $.100000 E+02$ & $.100000 \mathrm{E}+02$ \\
\hline$q+02$ & $100000 E+02$ & $.100000 E+02$ & $.100000 E+02$ & $.100000 \mathrm{E}+02$ \\
\hline+02 & $100000 E+02$ & $.100000 \mathrm{E}+02$ & $.100000 E+02$ & $.100000 \mathrm{E}+02$ \\
\hline $\mathrm{DE}+02$ & $100000 E+02$ & $.100000 E+02$ & $.100000 E+02$ & $.100000 E+02$ \\
\hline+02 & $.200000 E+02$ & $.200000 E+02$ & $.200000 \mathrm{E}+$ & $.200000 E+02$ \\
\hline $000 E+02$ & $200000 E+02$ & $.200000 E+02$ & $.200000 E+02$ & $.200000 \mathrm{E}+02$ \\
\hline+02 & $.200000 \mathrm{E}+02$ & $-.100000 E+02$ & -.1000 & $\mathrm{E}+02$ \\
\hline $00 E+02$ & $-.100000 E+02$ & $-.100000 E+02$ & $-.100000 E+02$ & -.100 \\
\hline $.000000 E+00$ & $.000000 E+00$ & $.000000 E+00$ & $.000000 E+00$ & +00 \\
\hline+00 & $.000000 E+00$ & $.000000 E+00$ & $.000000 E+00$ & $.000000 \mathrm{E}+00$ \\
\hline$O O E+O O$ & $.000000 E+00$ & $.000000 E+00$ & $.000000 E+00$ & $E+00$ \\
\hline+00 & .100000 & $.100000 E+02$ & .10 & +02 \\
\hline+02 & $100000 E+02$ & $.100000 \mathrm{E}+02$ & .1000 & +02 \\
\hline+02 & $.100000 E+02$ & $.100000 \mathrm{E}+02$ & .1000 & $E+02$ \\
\hline$O E+02$ & $100000 E+02$ & $.100000 \mathrm{E}+02$ & $.100000 E+02$ & $E+02$ \\
\hline+02 & .100000 & +02 & .10 & +02 \\
\hline$D E+02$ & $200000 E+02$ & $000 E+02$ & .2000 & +02 \\
\hline+02 & $200000 E+02$ & $.200000 E+02$ & .20000 & $0 \mathrm{E}+02$ \\
\hline+02 & $.200000 \mathrm{E}+02$ & $-.100000 E+02$ & $-.100000 E+02$ & -.100 \\
\hline-.1000 & $-.100000 E+02$ & $-.100000 E+02$ & $-.100000 E+02$ & -.100 \\
\hline .00 & .000000 & +00 & .00 & +00 \\
\hline .00 & .000000 & .00 & .00 & +00 \\
\hline .000000 & $.000000 E+00$ & $.000000 \mathrm{E}+00$ & $.000000 E+00$ & $E+00$ \\
\hline+00 & .100000 & $0000 E+02$ & .1000001 & $E+02$ \\
\hline+02 & +02 & +02 & +02 & $E+02$ \\
\hline .10 & .100000 & 02 & & +02 \\
\hline .100 & .100000 & .02 & .1000 & +02 \\
\hline .10000 & .100000 & 00001 & .1000 & +02 \\
\hline $.200000 E+02$ & $.2000 C, O E+02$ & $.200000 \mathrm{E}+02$ & $.200000 \mathrm{E}+02$ & $.200000 E+02$ \\
\hline $.200000 \mathrm{E}+02$ & $.200000 \mathrm{E}+02$ & $.200000 E+02$ & & $\mathrm{E}+02$ \\
\hline $.200000 E+02$ & $.200000 \mathrm{~F}$ & $0000 E+02$ & -.1000 & $1+02$ \\
\hline$-.100000 E+02$ & $.100000 \mathrm{E}$ & $-.100000 E+02$ & -.1000 & -.1000 \\
\hline $.000000 \mathrm{E}+00$ & $.000000 E+00$ & $.000000 \mathrm{E}+00$ & $.000000 \mathrm{E}+00$ & $.000000 E+00$ \\
\hline $.000000 \mathrm{E}+00$ & $.000000 \mathrm{E}+00$ & $.000000 \mathrm{E}+00$ & $.000000 E+00$ & $.000000 E+00$ \\
\hline $.000000 \mathrm{E}+00$ & $.000000 E+00$ & $.000000 E+00$ & $.000000 E_{1}+00$ & $.000000 \mathrm{E}+00$ \\
\hline $.000000 \mathrm{E}+00$ & $.100000 \mathrm{E}+02$ & $.100000 \mathrm{E}+02$ & $.100000 \mathrm{E}+02$ & $.100000 \mathrm{E}+02$ \\
\hline $.100000 E+02$ & $.100000 E+02$ & $.100000 E+02$ & $.100000 \mathrm{E}+02$ & $0000 E+02$ \\
\hline & $.100000 \mathrm{E}+02$ & $.100000 \mathrm{E}+02$ & $.100000 \mathrm{E}+02$ & $.100000 \mathrm{E}+02$ \\
\hline $.100000 \mathrm{E}+02$ & $.100000 \mathrm{E}+02$ & $.100000 \mathrm{E}+02$ & $.100000 \mathrm{E}+02$ & $100000 E+02$ \\
\hline
\end{tabular}


TABLE C.5 (Cont'd)

\begin{abstract}
$.100000 \mathrm{E}+02$ $.100000 \mathrm{E}+02$ $.100000 \mathrm{E}+02$ $.100000 \mathrm{E}+02$ $.790000 \mathrm{E}+02$ $.500000 \mathrm{E}+02$ $.500000 \mathrm{E}+02$ $.500000 \mathrm{E}+02$ $.500000 \mathrm{E}+02$ $.500000 \mathrm{E}+02$

$-.100000 \mathrm{E}+02$

$-.100000 \mathrm{E}+02$

$-.100000 \mathrm{E}+02$ $.200000 \mathrm{E}+02$ $.200000 \mathrm{E}+02$ $.200000 \mathrm{E}+02$ $.200000 \mathrm{E}+02$ $.200000 \mathrm{E}+02$ $.200000 \mathrm{E}+02$ $.200000 E+02$

$-.100000 E+02$

-.100000E+02

$-.100000 \mathrm{E}+02$

$-.100000 \mathrm{E}+02$

-.100000E+02

$-.100000 E+02$

$.000000 \mathrm{E}+00$ $.000000 E+00$ $.000000 \mathrm{E}+00$
\end{abstract}
$.100000 E+02$ $.100000 \mathrm{E}+02$ .100000E+02 $.100000 \mathrm{E}+02$ $.790000 E+02$ $.500000 \mathrm{E}+02$ $.500000 \mathrm{E}+02$ $.500000 \mathrm{E}+02$ $.500000 \mathrm{E}+02$ $.500000 \mathrm{E}+02$
$-.100000 \mathrm{E}+02$
$-.100000 \mathrm{E}+02$
$-.100000 E+02$ $.200000 \mathrm{E}+02$ $.200000 \mathrm{E}+02$ $.200000 E+02$ $.200000 \mathrm{E}+02$ $.200000 \mathrm{E}+02$ $.200000 \mathrm{E}+02$ $.200000 E+02$
$-.100000 E+02$
$-.100000 \mathrm{E}+02$
$-.100000 \mathrm{E}+02$
$-.100000 E+02$
$-.100000 E+02$
$-.100000 \mathrm{E}+02$
$.000000 E+00$ $.000000 \mathrm{E}+00$ $.000000 \mathrm{E}+00$

$.100000 \mathrm{E}+02$ $.100000 \mathrm{E}+02$ $.100000 \mathrm{E}+02$ $.790000 \mathrm{E}+02$ $.790000 \mathrm{E}+02$ $.500000 \mathrm{E}+02$ $.500000 E+02$ $.500000 \mathrm{E}+02$ $.500000 \mathrm{E}+02$ $.500000 \mathrm{E}+02$

$-.100000 \mathrm{E}+02$

-.100000E+02

$-.100000 E+02$ $.200000 \mathrm{E}+02$ $.200000 \mathrm{E}+02$ $.200000 \mathrm{E}+02$ $.200000 \mathrm{E}+02$ $.200000 E+02$ $.200000 \mathrm{E}+02$

$-.100000 \mathrm{E}+02$

$-.100000 \mathrm{E}+02$

$-.100000 \mathrm{E}+02$

$-.100000 \mathrm{E}+02$

$-.100000 \mathrm{E}+02$

$-.100000 \mathrm{E}+02$

$-.100000 \mathrm{E}+02$ $.000000 \mathrm{E}+00$ $.000000 \mathrm{E}+00$ $.000000 E+00$
$.100000 \mathrm{E}+02$ $.100000 \mathrm{E}+02$ $.100000 \mathrm{E}+02$ $.790000 \mathrm{E}+02$ $.790000 \mathrm{E}+02$ $.500000 \mathrm{E}+02$ $.500000 \mathrm{E}+02$ $.500000 \mathrm{E}+02$ $.500000 \mathrm{E}+02$ $.500000 \mathrm{E}+02$ $-.100000 E+02$ -. 100000E+02

-. $1.00000 \mathrm{E}+02$ $.200000 \mathrm{E}+02$ $.200000 \mathrm{E}+02$ $.200000 \mathrm{E}+02$ $.200000 E+02$ $.200000 E+02$ $.200000 E+02$

$-.100000 \mathrm{E}+02$

$-.100000 \mathrm{E}+02$

$-.100000 \mathrm{E}+02$

$-.100000 \mathrm{E}+02$

$-.100000 \mathrm{E}+02$

$-.100000 \mathrm{E}+02$

$-.100000 \mathrm{E}+02$ $.000000 \mathrm{E}+00$ $.000000 \mathrm{E}+00$ $.000000 E+00$
$.100000 \mathrm{E}+02$ $.200000 \mathrm{E}+02$ $.100000 \mathrm{E}+02$ $.790000 \mathrm{E}+02$ $.790000 \mathrm{E}+02$ $.500000 \mathrm{E}+02$ $.500000 \mathrm{E}+02$ $.500000 \mathrm{E}+02$ $.500000 \mathrm{E}+02$ $-.100000 \mathrm{E}+02$ $-.100000 \mathrm{E}+02$ -.100000E+02

$-.100000 \mathrm{E}+02$ $.200000 \mathrm{E}+02$ $.200000 \mathrm{E}+02$ $.200000 \mathrm{E}+02$ $.200000 \mathrm{E}+02$ $.200000 \mathrm{E}+02$ $.200000 \mathrm{E}+02$

$-.100000 \mathrm{E}+02$

$-.100000 \mathrm{E}+02$

$-.100000 \mathrm{E}+02$

$-.100000 \mathrm{E}+02$

$-.100000 \mathrm{E}+02$

$-.100000 E+02$ $.000000 \mathrm{E}+00$ $.000000 \mathrm{E}+00$ $.000000 \mathrm{E}+00$ $.000000 \mathrm{E}+00$ 


\section{$35 / 36$}

Appendix D:

Default Battery Data Files 
TABLE D.1 Default Data Set for Sodlum/Sulfur Batterles, 1988 Technology

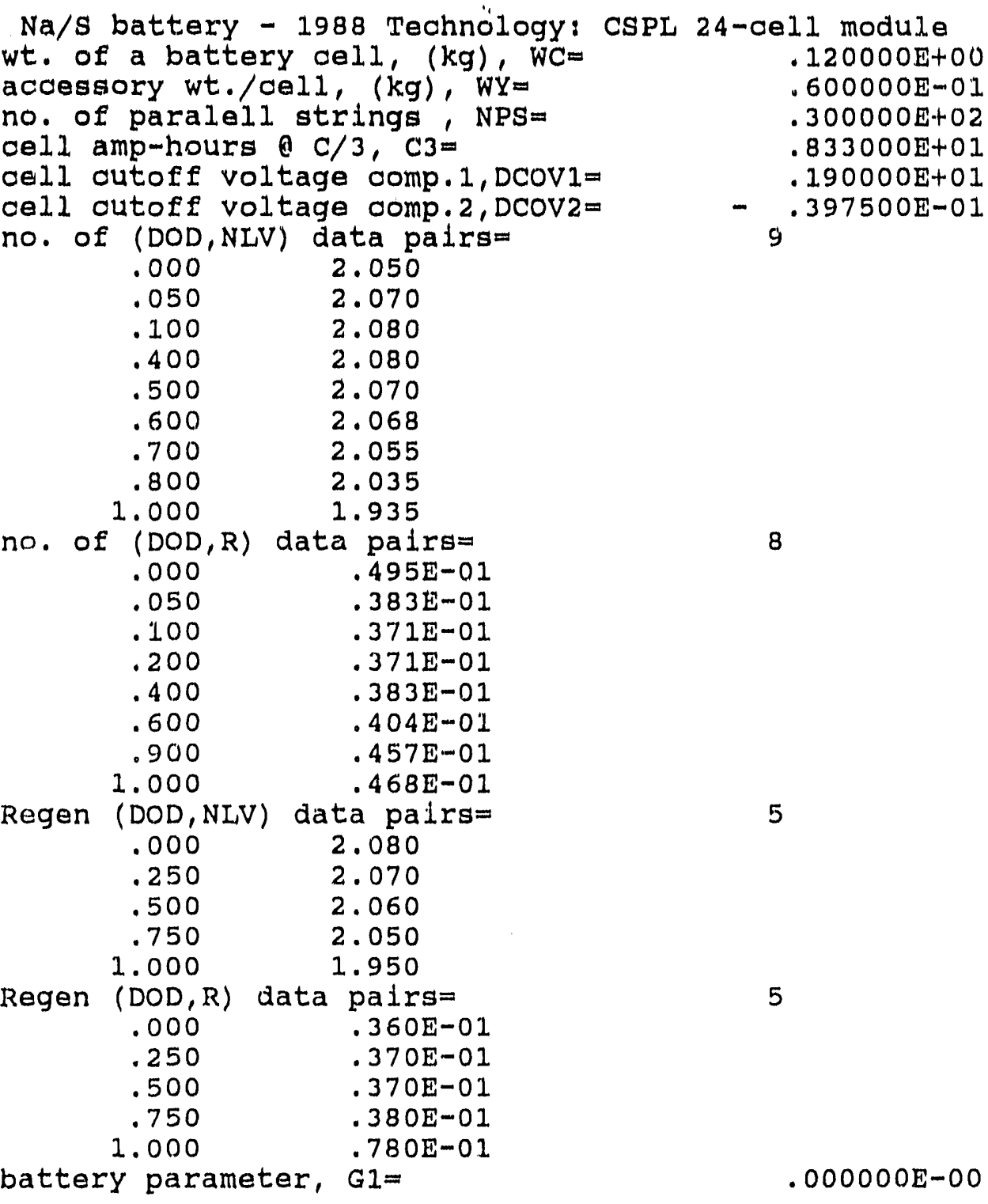


TABLE D.2 Default Data Set for Sodium/Sulfur Batterles, 1989 Technology

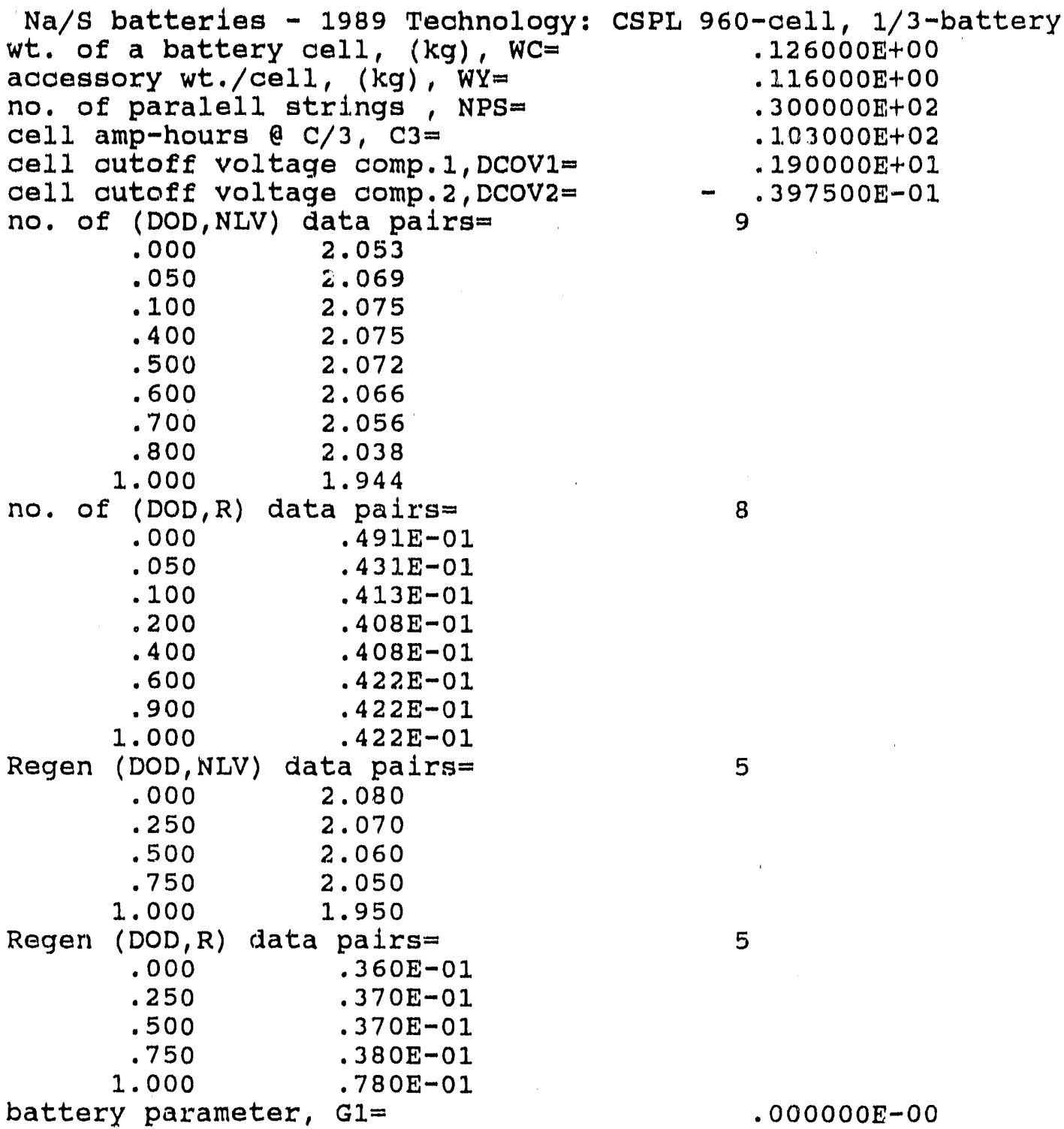


TABLE D.3 Default Data Set for Nickel//ron NIF220 Batterles

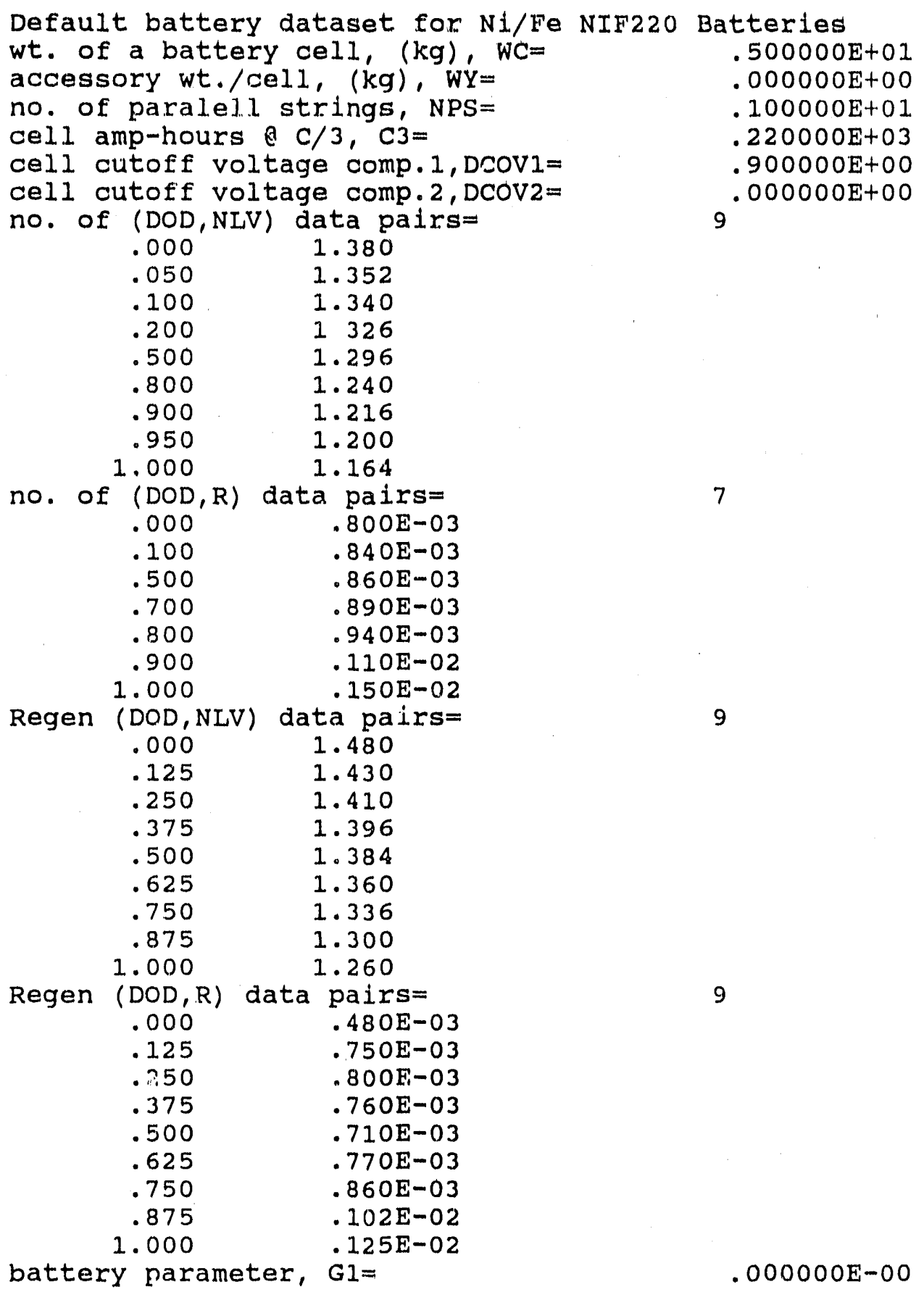


TABLE D.4 Default Data Set for Tubular L/A 3ET205 Batteries

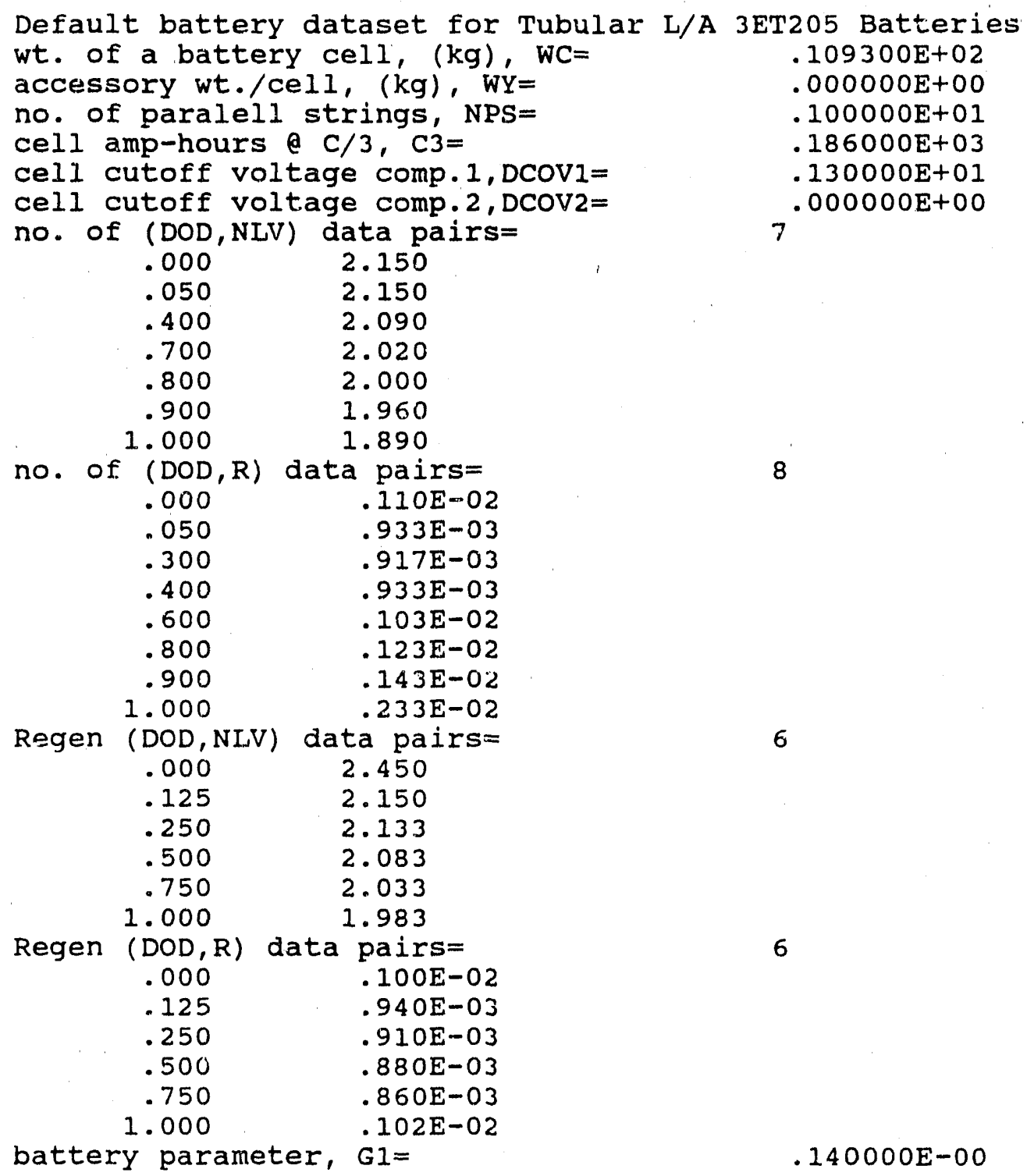




\section{$41 / 42$}

TABLE D.5 Default Data Set for Zinc/Bromine Batteries

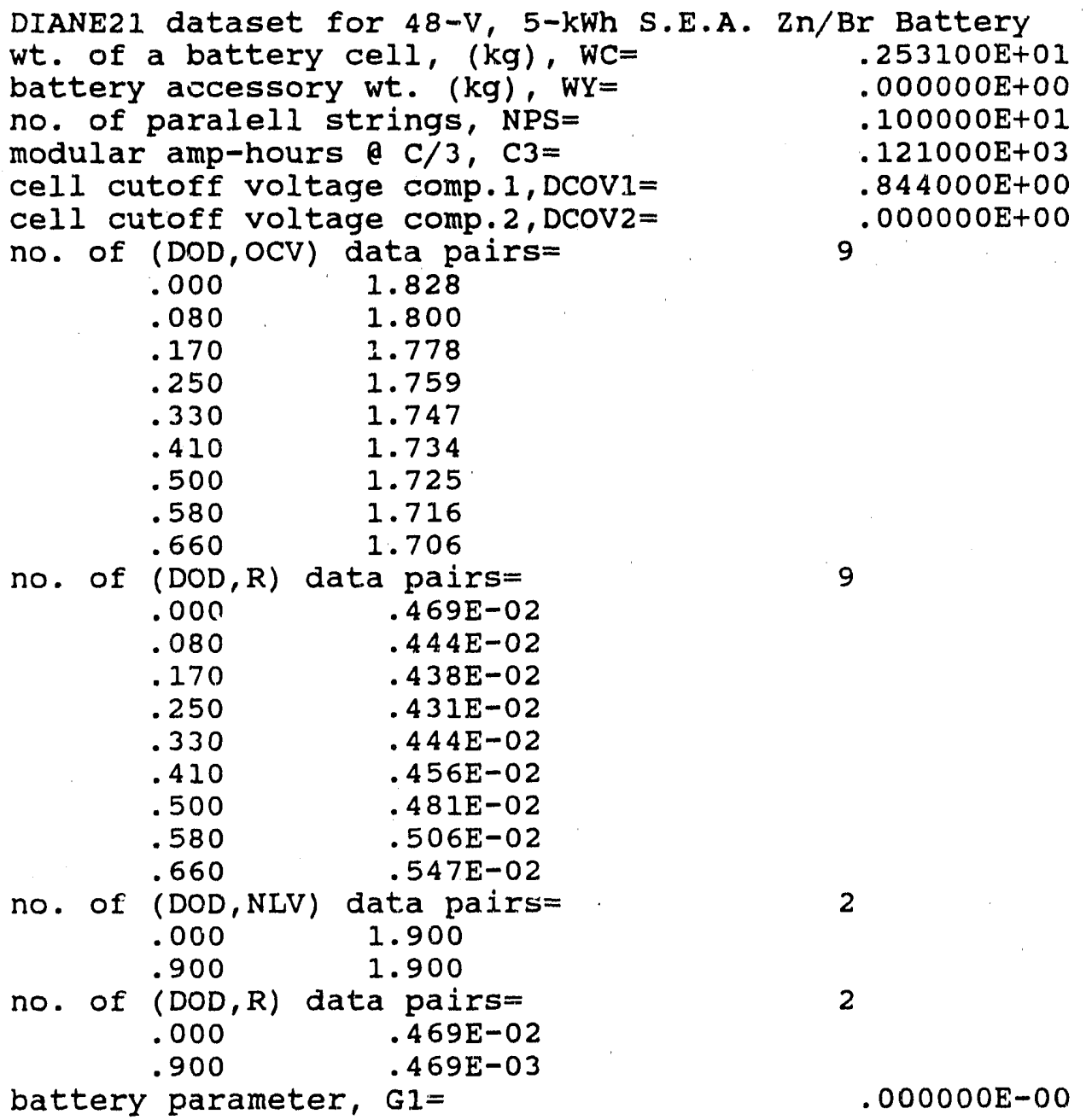




\section{$43 / 44$}

Appendix E:

Sample Problems 
SAMPLE 1: IETV-1/J227aD/3ET205 System with Regenerative Braking

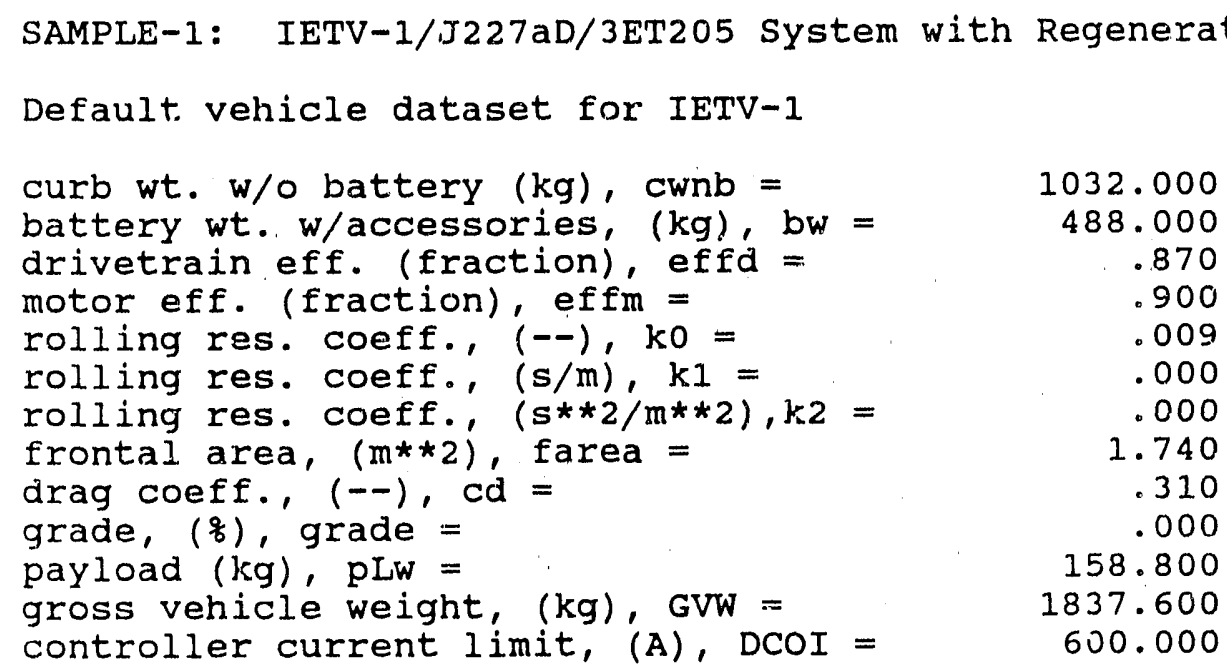

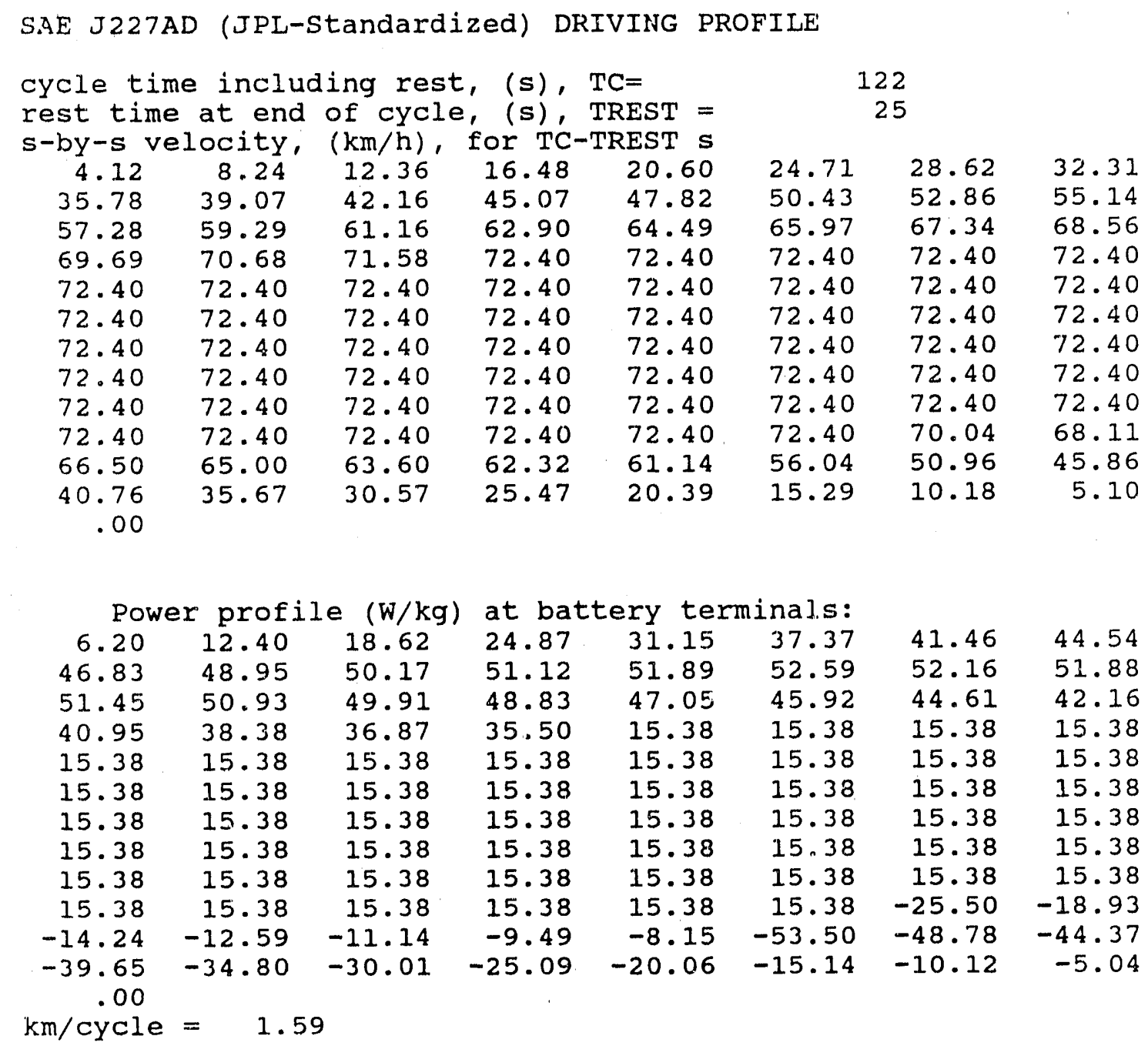


SAMPLE 1: IETV-1/J227aD/E3T205 System with Regenerative Braking (Cont'd)

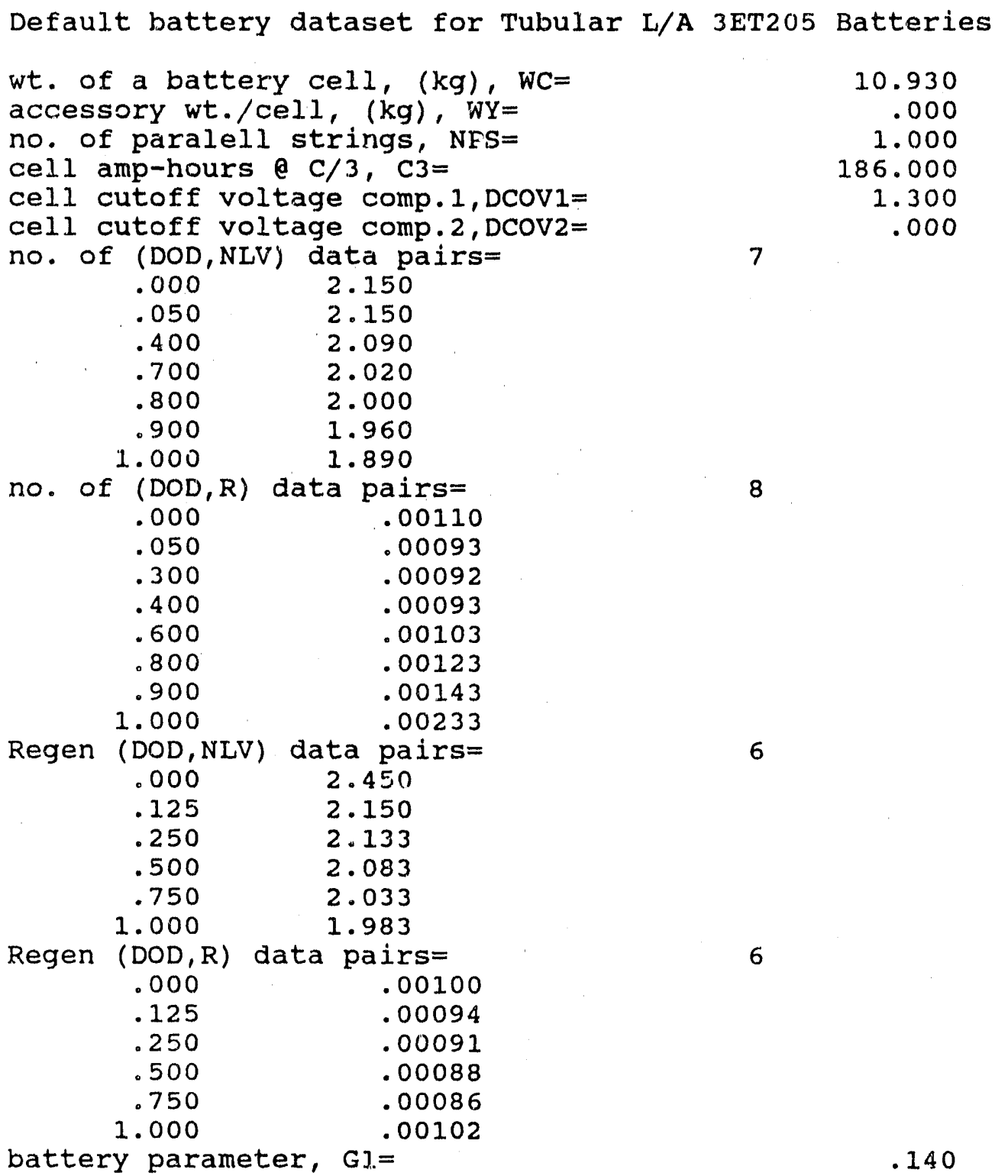


SAMPLE 1: IETV-1/J227aD/E3T205 System with Regenerative Braking (Cont'd)

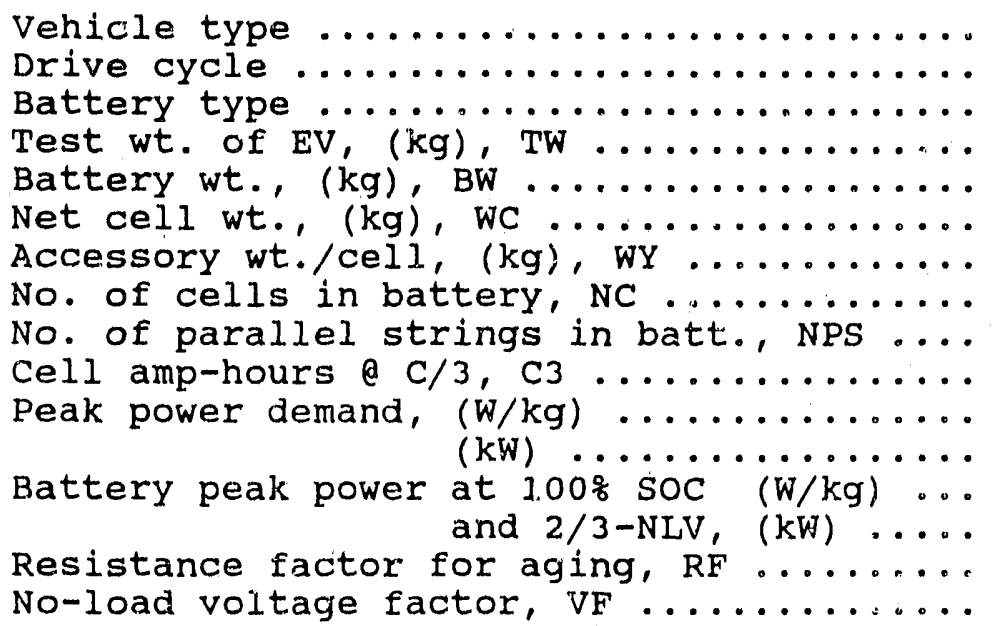

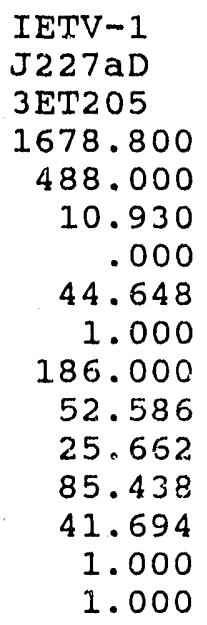

\begin{tabular}{|c|c|c|c|c|c|c|c|c|c|}
\hline Driving & Time & Range & Maxil & am I & Min & $\mathrm{am} \mathrm{V}$ & Amp - & bur & kWh \\
\hline Profile & $\mathrm{h}$ & $\mathrm{km}$ & Cell & Batt & Cell & Batt & Cell & Batt & Batt \\
\hline 1 & .03 & 1.6 & 318.2 & 318.2 & 1.806 & 80.6 & 3.0 & 3.0 & .3 \\
\hline 2 & .07 & 3.2 & 313.9 & 313.9 & 1.831 & 81.8 & 6.0 & 6.0 & .5 \\
\hline 3 & .10 & 4.8 & 309.8 & 309.8 & 1.855 & 82.8 & 9.0 & 9.0 & .8 \\
\hline 4 & .14 & 6.4 & 309.1 & 309.1 & 1.860 & 83.0 & 11.9 & 11.9 & 1.0 \\
\hline 5 & .17 & 7.9 & 309.7 & 309.7 & 1.856 & 82.9 & 14.9 & 14.9 & 1.3 \\
\hline 6 & .20 & 9.5 & 310.2 & 310.2 & 1.853 & 82.7 & 17.9 & 17.9 & 1.6 \\
\hline 7 & .24 & 11.1 & 31.0 .8 & 310.8 & 1.849 & 82.6 & 20.9 & 20.9 & 1.8 \\
\hline 8 & .27 & 12.7 & 311.4 & 311.4 & 1.846 & 82.4 & 23.9 & 23.9 & 2.1 \\
\hline 9 & .31 & 14.3 & 312.0 & 312.0 & 1.842 & 82.3 & 26.9 & 26.9 & 2.3 \\
\hline 10 & .34 & 15.9 & 312.6 & 312.6 & 1.839 & 82.1 & 29.9 & 29.9 & 2.6 \\
\hline 11 & .37 & 17.5 & 313.2 & 313.2 & 1.835 & 81.9 & 32.9 & 32.9 & 2.9 \\
\hline 12 & .41 & 19.1 & 313.8 & 313.8 & 1.832 & 81.8 & 35.9 & 35.9 & 3.1 \\
\hline 13 & .44 & 20.7 & 314.4 & 314.4 & 1.828 & 81.6 & 38.9 & 38.9 & 3.4 \\
\hline 14 & .47 & 22.2 & 315.0 & 315.0 & 1.825 & 81.5 & 41.9 & 41.9 & 3.7 \\
\hline 15 & .51 & 23.8 & 315.6 & 315.6 & 1.821 & 81.3 & 44.9 & 44.9 & 3.9 \\
\hline 16 & .54 & 25.4 & 316.2 & 316.2 & 1.818 & 81.2 & 48.0 & 48.0 & 4.2 \\
\hline 17 & .58 & 27.0 & 317.0 & 317.0 & 1.813 & 80.9 & 51.0 & 51.0 & 4.4 \\
\hline 18 & .61 & 28.6 & 318.0 & 318.0 & 1.808 & 80.7 & 54.0 & 54.0 & 4.7 \\
\hline 19 & .64 & 30.2 & 318.9 & 318.9 & 1.802 & 80.5 & 57.1 & 57.1 & 5.0 \\
\hline 20 & .68 & 31.8 & 319.8 & 319.8 & 1.797 & 80.2 & 60.2 & 60.2 & 5.2 \\
\hline 21 & .71 & 33.4 & 320.8 & 320.8 & 1.792 & 80.0 & 63.2 & 63.2 & 5.5 \\
\hline 22 & .75 & 35.0 & 322.3 & 322.3 & 1.783 & 79.6 & 66.3 & 66.3 & 5.7 \\
\hline 23 & .78 & 36.5 & 324.0 & 324.0 & 1.774 & 79.2 & 69.4 & 69.4 & 6.0 \\
\hline 24 & .81 & 38.1 & 325.8 & 325.8 & 1.764 & 78.8 & 72.5 & 72.5 & 6.3 \\
\hline 25 & .85 & 39.7 & 327.6 & 327.6 & 1.755 & 78.3 & 75.6 & 75.6 & 6.5 \\
\hline 26 & .88 & 41.3 & 329.4 & 329.4 & 1.745 & 77.9 & 78.8 & 78.8 & 6.8 \\
\hline 27 & .92 & 42.9 & 331.3 & 331.3 & 1.735 & 77.4 & 81.9 & 81.9 & 7.0 \\
\hline 28 & .95 & 44.5 & 333.3 & 333.3 & 1.724 & 77.0 & 85.1 & 85.1 & 7.3 \\
\hline 29 & .98 & 46.1 & 335.3 & 335.3 & 1.714 & 76.5 & 88.2 & 88.2 & 7.6 \\
\hline 30 & 1.02 & 47.7 & 337.4 & 337.4 & 1.704 & 76.1 & 91.4 & 91.4 & 7.8 \\
\hline 31 & 1.05 & 49.3 & 339.5 & 339.5 & 1.693 & 75.6 & 94.6 & 94.6 & 8.1 \\
\hline
\end{tabular}


SAMPLE 1: IETV-1/J227aD/E3T205 System with Regenerative Braklng (Cont'd)

$\begin{array}{rrrrrrrrrr}32 & 1.08 & 50.8 & 342.7 & 342.7 & 1.677 & 74.9 & 97.8 & 97.8 & 8.3 \\ 33 & 1.12 & 52.4 & 346.0 & 346.0 & 1.661 & 74.2 & 101.1 & 101.1 & 8.6 \\ 34 & 1.15 & 54.0 & 349.5 & 349.5 & 1.645 & 73.4 & 104.3 & 104.3 & 8.9 \\ 35 & 1.19 & 55.6 & 353.1 & 353.1 & 1.628 & 72.7 & 107.6 & 107.6 & 9.1 \\ 36 & 1.22 & 57.2 & 356.8 & 356.8 & 1.611 & 71.9 & 110.9 & 110.9 & 9.4 \\ 37 & 1.25 & 58.8 & 360.7 & 360.7 & 1.594 & 71.2 & 114.3 & 114.3 & 9.6 \\ 38 & 1.29 & 60.4 & 364.7 & 364.7 & 1.576 & 70.4 & 117.6 & 117.6 & 9.9 \\ 39 & 1.32 & 62.0 & 369.0 & 369.0 & 1.558 & 69.6 & 121.0 & 121.0 & 10.2 \\ 40 & 1.36 & 63.6 & 374.1 & 374.1 & 1.536 & 68.6 & 124.4 & 124.4 & 10.4 \\ 41 & 1.39 & 65.1 & 384.2 & 384.2 & 1.496 & 66.8 & 127.9 & 127.9 & 10.7 \\ 42 & 1.42 & 66.7 & 396.0 & 396.0 & 1.452 & 64.8 & 131.4 & 131.4 & 11.0 \\ 43 & 1.46 & 68.3 & 410.0 & 410.0 & 1.402 & 62.6 & 135.0 & 135.0 & 11.2 \\ 44 & 1.49 & 69.9 & 433.8 & 433.8 & 1.320 & 58.9 & 138.8 & 138.8 & 11.5 \\ \text { Driving } & \text { Time } & \text { Range } & \text { Maximum I } & \text { Minimum V } & \text { Amp-Hour } & \text { kWh } \\ \text { Profile } & \mathrm{h} & \mathrm{km} & \text { Cell } & \text { Batt } & \text { Cell } & \text { Batt } & \text { Cell } & \text { Batt } & \text { Batt }\end{array}$

\begin{tabular}{cccccccc} 
Cell voltage of & \multicolumn{7}{c}{ first driving profile: } \\
2.115 & 2.078 & 2.040 & 2.001 & 1.959 & 1.916 & 1.887 & 1.864 \\
1.847 & 1.832 & 1.823 & 1.816 & 1.811 & 1.806 & 1.810 & 1.814 \\
1.818 & 1.823 & 1.832 & 1.841 & 1.855 & 1.864 & 1.874 & 1.892 \\
1.901 & 1.920 & 1.930 & 1.940 & 2.064 & 2.064 & 2.064 & 2.065 \\
2.065 & 2.065 & 2.065 & 2.065 & 2.065 & 2.065 & 2.065 & 2.065 \\
2.065 & 2.065 & 2.065 & 2.065 & 2.065 & 2.065 & 2.065 & 2.065 \\
2.065 & 2.065 & 2.065 & 2.065 & 2.065 & 2.065 & 2.065 & 2.065 \\
2.065 & 2.065 & 2.066 & 2.066 & 2.066 & 2.066 & 2.066 & 2.066 \\
2.066 & 2.066 & 2.066 & 2.066 & 2.066 & 2.066 & 2.066 & 2.066 \\
2.066 & 2.066 & 2.066 & 2.066 & 2.066 & 2.066 & 2.509 & 2.482 \\
2.462 & 2.455 & 2.449 & 2.442 & 2.436 & 2.621 & 2.603 & 2.587 \\
2.568 & 2.549 & 2.530 & 2.510 & 2.490 & 2.469 & 2.447 & 2.425 \\
2.150 & & & & & & &
\end{tabular}

Cell current of first driving profile:

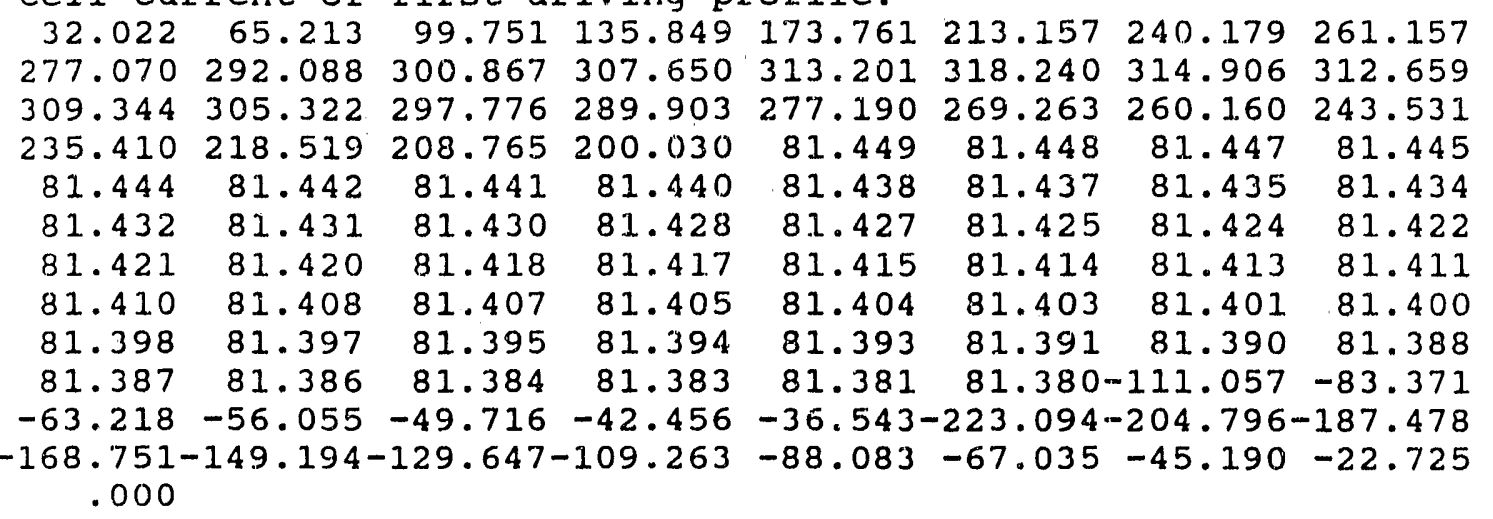


SAMPLE 1: IETV-1/J227aD/E3T205 System with Regenerative Braking (Cont'd)

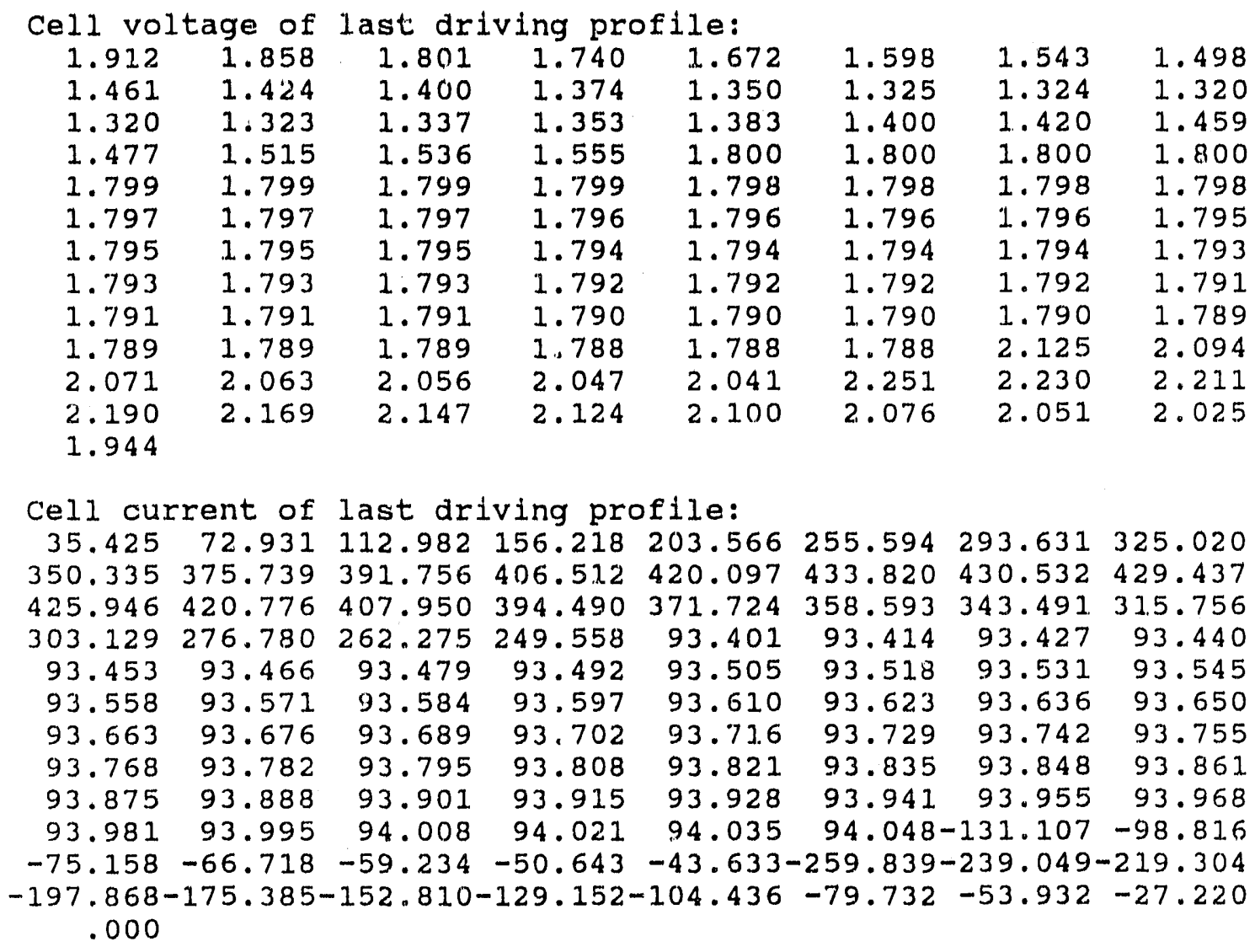

Projected maximum range is Capacity removed is Regeneration capacity is

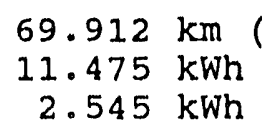

43.451 miles)

or $138.786 \mathrm{Ah}$

or $25.378 \mathrm{Ah}$ 
SAMPLE 1: IETV-1/J227aD/E3T205 System with Regeneratlve Braking (Cont'd)

$\star * * \star *$ Vehicle velocity with maximurn-power acceleration

\begin{tabular}{cr} 
Time (s) & \multicolumn{1}{c}{$\mathrm{km} / \mathrm{h}$} \\
\hline 1 & 20.11 \\
2 & 32.49 \\
3 & 41.93 \\
4 & 49.77 \\
5 & 56.57 \\
6 & 62.65 \\
7 & 68.15 \\
8 & 73.18 \\
9 & 77.82 \\
10 & 82.15 \\
11 & 86.19 \\
12 & 90.02 \\
13 & 93.62 \\
14 & 97.03 \\
15 & 100.26 \\
16 & 103.33 \\
17 & 106.25 \\
18 & 109.03 \\
19 & 111.69 \\
20 & 114.23 \\
21 & 116.66 \\
22 & 119.01 \\
23 & 121.26 \\
24 & 123.42 \\
25 & 125.50 \\
26 & 127.48 \\
27 & 129.39
\end{tabular}

\begin{tabular}{l} 
mph \\
\hdashline 12.50 \\
20.20 \\
26.06 \\
30.93 \\
35.16 \\
38.94 \\
42.35 \\
45.48 \\
48.37 \\
51.06 \\
53.57 \\
55.95 \\
58.19 \\
60.31 \\
62.31 \\
64.22 \\
66.04 \\
67.77 \\
69.42 \\
71.00 \\
72.51 \\
73.97 \\
75.37 \\
76.71 \\
78.00 \\
79.23 \\
80.42
\end{tabular}

$\mathrm{km}$
.00
.01
.02
.03
.05
.06
.08
.10
.12
.15
.17
.19
.22
.25
.27
.30
.33
.36
.39
.42
.45
.49
.52
.55
.59
.62
.66

mile

.00

.01

.01

.02

.03

.04

.05

.06

.08

.09

.10

.12

.14

.15

.17

.19

.21

.22

.24

.26

.28

.30

.32

.34

.37

.39

.41

This is the end of the case. 
SAMPLE 2: Same as SAMPLE-1 Except Power Proflle is Input

SAMPLE-2: Same As SAMPLE-1 Exoept Power Prof1le is Input

Default vehicle dataset for IETV-1

curb wt. w/o battery $(\mathrm{kg})$, awnb $=$ battery wt. w/accessorles, $(\mathrm{kg}), \mathrm{bw}=$ drivetrain eff. (fraction), effd = motor eft. (fraction), effm = rolling res. coeff., (--), $\mathrm{k0}=$ rolling res. coeff., $(\mathrm{s} / \mathrm{m}), \mathrm{k} 1=$ rolling res. coeff., $(s * \star 2 / m * \star 2), k 2 \Rightarrow$ frontal area, $(m * * 2)$, farea $=$ drag coeff., $(--), \mathrm{cd}=$ grade, ( 8$)$, grade $=$ payload $(\mathrm{kg}), \mathrm{pLw}=$ gross vehicle weight, $(\mathrm{kg}), \mathrm{GVW}=$ controller current limit, (A), DCOI =

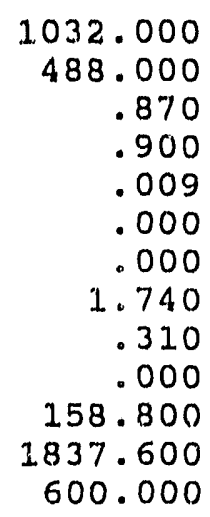

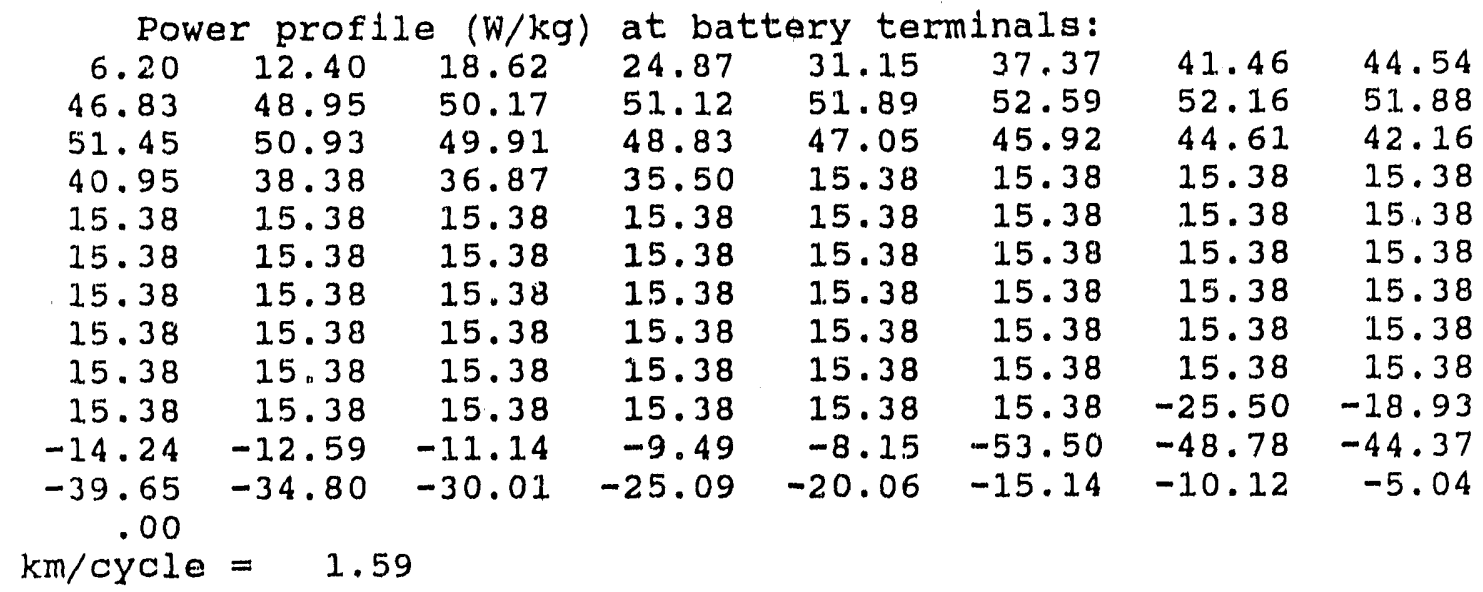


SAMPLE 2: Same as SAMPLE-1 Except Power Proflle is Input (Cont'd)

Default battery dataset for Tubular L/A 3ET205 Batteries

wt. of a battery cell, (kg), $W C=$ adcessory wt. /cell, $(\mathrm{kg}), W Y=$

10.930

.000

no. of paralell strings, NPS =

cell amp-hours @ $\mathrm{C} / 3, \mathrm{C} 3=$

cell cutoff voltage comp. 1, DCOVI=

cell cutoff voltage comp. 2, DCOV2=

no. of (DOD, NLV) data patrs $=$

$.000 \quad 2.150$

$.050 \quad 2.150$

$.400 \quad 2.090$

$.700 \quad 2.020$

$.800 \quad 2.000$

$.900 \quad 1.960$

$1.000 \quad 1.890$

no. of $(D O D, R)$ data pairs $=$

$.000 \quad .00110$

$.050 \quad .00093$

$.300 \quad .00092$

$.400 \quad .00093$

$.600 \quad .00103$

$.800 \quad .00123$

$.900 \quad .00143$

$1.000 \quad .00233$

Regen (DOD, NLV) data pairs=

$.000 \quad 2.450$

$.125 \quad 2.150$

$.250 \quad 2.133$

$.500 \quad 2.083$

$.750 \quad 2.033$

$1.000 \quad 1.983$

Regen ( $D O D, R$ ) data pairs=

$.000 \quad .00100$

$.125 \quad .00094$

$.250 \quad .00091$

$.500 \quad .00088$

$.750 \quad .00086$

$1.000 \quad .00102$

battery parameter, $\mathrm{GI}=$
6

1.000

186.000

1.300

.000

7

8

6 
3AMPLE 2: Same as SAMPLE-1 Exoept Power Proflle is Input (Conit'd)

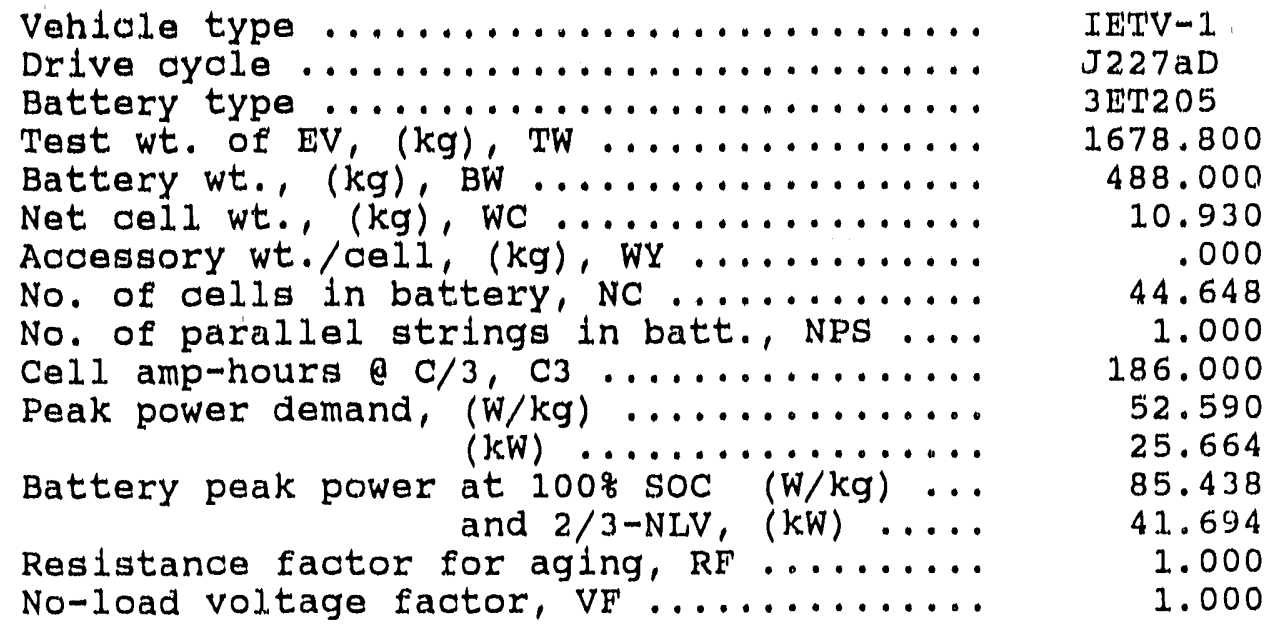

\begin{tabular}{ccccccccrr} 
Driving & Time & Range & \multicolumn{2}{c}{ Maximum I } & \multicolumn{2}{c}{ Minimum V } & \multicolumn{2}{c}{ Amp-Hour } & kWh \\
Profile & h & km & Celi & Batt & Cel1 & Batt & Celi & Batt & Batt \\
1 & .03 & 1.6 & 318.3 & 318.3 & 1.806 & 80.6 & 3.0 & 3.0 & .3 \\
2 & .07 & 3.2 & 313.9 & 313.9 & 1.831 & 81.8 & 6.0 & 6.0 & .5 \\
3 & .10 & 4.8 & 309.8 & 309.8 & 1.855 & 82.8 & 9.0 & 9.0 & .8 \\
4 & .14 & 6.4 & 309.1 & 309.1 & 1.860 & 83.0 & 11.9 & 11.9 & 1.0 \\
5 & .17 & 8.0 & 309.7 & 309.7 & 1.856 & 82.9 & 14.9 & 14.9 & 1.3 \\
6 & .20 & 9.5 & 310.3 & 310.3 & 1.853 & 82.7 & 17.9 & 17.9 & 1.6 \\
7 & .24 & 11.1 & 310.8 & 310.8 & 1.849 & 82.6 & 20.9 & 20.9 & 1.8 \\
8 & .27 & 12.7 & 311.4 & 311.4 & 1.846 & 82.4 & 23.9 & 23.9 & 2.1 \\
9 & .31 & 14.3 & 312.0 & 312.0 & 1.842 & 82.3 & 26.9 & 26.9 & 2.3 \\
10 & .34 & 15.9 & 312.6 & 312.6 & 1.839 & 82.1 & 29.9 & 29.9 & 2.6 \\
11 & .37 & 17.5 & 313.2 & 313.2 & 1.835 & 81.9 & 32.9 & 32.9 & 2.9 \\
12 & .41 & 19.1 & 313.8 & 313.8 & 1.832 & 81.8 & 35.9 & 35.9 & 3.1 \\
13 & .44 & 20.7 & 314.4 & 314.4 & 1.828 & 81.6 & 38.9 & 38.9 & 3.4 \\
14 & .47 & 22.3 & 315.0 & 315.0 & 1.825 & 81.5 & 41.9 & 41.9 & 3.7 \\
15 & .51 & 23.9 & 315.6 & 315.6 & 1.821 & 81.3 & 44.9 & 44.9 & 3.9 \\
16 & .54 & 25.4 & 316.2 & 316.2 & 1.818 & 81.2 & 48.0 & 48.0 & 4.2 \\
17 & .58 & 27.0 & 317.1 & 317.1 & 1.813 & 80.9 & 51.0 & 51.0 & 4.4 \\
18 & .61 & 28.6 & 318.0 & 318.0 & 1.808 & 80.7 & 54.0 & 54.0 & 4.7 \\
19 & .64 & 30.2 & 318.9 & 318.9 & 1.802 & 80.5 & 57.1 & 57.1 & 5.0 \\
20 & .68 & 31.8 & 319.8 & 319.8 & 1.797 & 80.2 & 60.2 & 60.2 & 5.2 \\
21 & .71 & 33.4 & 320.8 & 320.8 & 1.792 & 80.0 & 63.2 & 63.2 & 5.5 \\
22 & .75 & 35.0 & 322.3 & 322.3 & 1.783 & 79.6 & 66.3 & 66.3 & 5.7 \\
23 & .78 & 36.6 & 324.0 & 324.0 & 1.774 & 79.2 & 69.4 & 69.4 & 6.0 \\
24 & .81 & 38.2 & 325.8 & 325.8 & 1.764 & 78.8 & 72.5 & 72.5 & 6.3 \\
25 & .85 & 39.8 & 327.6 & 327.6 & 1.755 & 78.3 & 75.6 & 75.6 & 6.5 \\
26 & .88 & 41.3 & 329.5 & 329.5 & 1.745 & 77.9 & 78.7 & 78.7 & 6.8 \\
27 & .92 & 42.9 & 331.4 & 331.4 & 1.735 & 77.4 & 81.9 & 81.9 & 7.0 \\
28 & .95 & 44.5 & 333.3 & 333.3 & 1.724 & 77.0 & 85.0 & 85.0 & 7.3 \\
29 & .98 & 46.1 & 335.3 & 335.3 & 1.714 & 76.5 & 88.2 & 88.2 & 7.6 \\
30 & 1.02 & 47.7 & 337.4 & 337.4 & 1.704 & 76.1 & 91.4 & 91.4 & 7.8
\end{tabular}


SAMPLE 2: Same as SAMPLE-1 Except Power Proflle is Input (Cont'd)

$\begin{array}{rrrrrrrrrr}31 & 1.05 & 49.3 & 339.6 & 339.6 & 1.693 & 75.6 & 94.6 & 94.6 & 8.1 \\ 32 & 1.08 & 50.9 & 342.7 & 342.7 & 1.677 & 74.9 & 97.8 & 97.8 & 8.3 \\ 33 & 1.12 & 52.5 & 346.0 & 346.0 & 1.661 & 74.2 & 101.1 & 101.1 & 8.6 \\ 34 & 1.15 & 54.1 & 349.5 & 349.5 & 1.645 & 73.4 & 104.3 & 104.3 & 8.9 \\ 35 & 1.19 & 55.7 & 353.1 & 353.1 & 1.628 & 72.7 & 107.6 & 107.6 & 9.1 \\ 36 & 1.22 & 57.2 & 356.9 & 356.9 & 1.611 & 71.9 & 110.9 & 110.9 & 9.4 \\ 37 & 1.25 & 58.8 & 360.7 & 360.7 & 1.594 & 71.2 & 114.3 & 114.3 & 9.6 \\ 38 & 1.29 & 60.4 & 364.7 & 364.7 & 1.576 & 70.4 & 117.6 & 117.6 & 9.9 \\ 39 & 1.32 & 62.0 & 369.0 & 369.0 & 1.558 & 69.6 & 121.0 & 121.0 & 10.2 \\ 40 & 1.36 & 63.6 & 374.1 & 374.1 & 1.536 & 68.6 & 124.4 & 124.4 & 10.4 \\ 41 & 1.39 & 65.2 & 384.2 & 384.2 & 1.496 & 66.8 & 127.9 & 127.9 & 10.7 \\ 42 & 1.42 & 66.8 & 396.0 & 396.0 & 1.452 & 64.8 & 131.4 & 131.4 & 11.0 \\ 43 & 1.46 & 68.4 & 410.0 & 410.0 & 1.402 & 62.6 & 135.0 & 135.0 & 11.2 \\ 44 & 1.49 & 70.0 & 433.7 & 433.7 & 1.321 & 59.0 & 138.8 & 138.8 & 11.5 \\ \text { Driving } & \text { Time } & \text { Range } & \text { Maximum I } & \text { Minimum V } & \text { Amp-Hour } & \mathrm{kWh} \\ \text { Profile } & \mathrm{h} & \text { km } & \text { Cell } & \text { Batt } & \text { Celi } & \text { Batt } & \text { Cel1 } & \text { Batt } & \text { Batt }\end{array}$

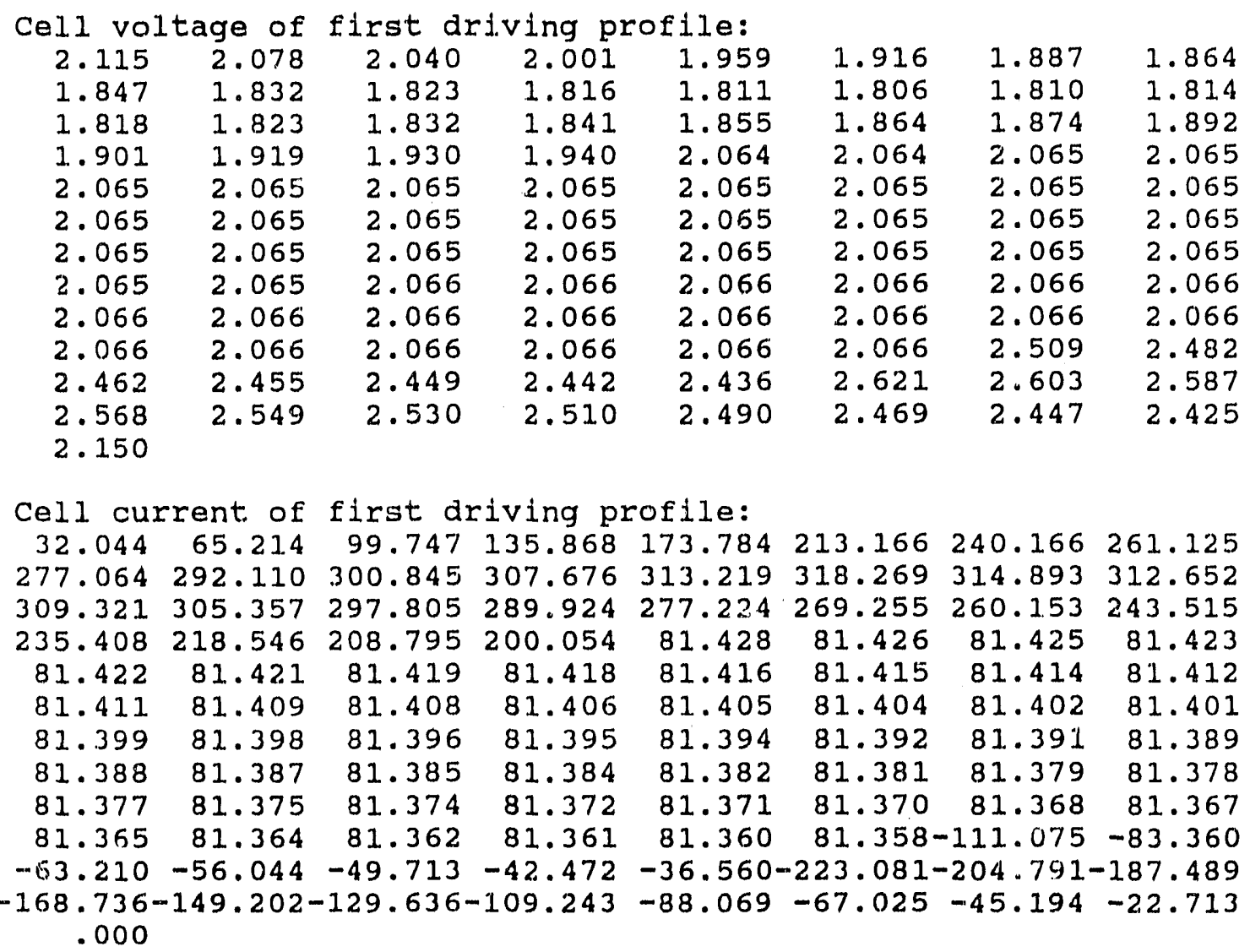


SAMPLE 2: Same as SAMPLE-1 Exoept Power Proflle is Input (Cont'd)

$\begin{array}{cccccccc}\text { Cel1 voltage of } & \text { last driving profile: } \\ 1.912 & 1.859 & 1.801 & 1.740 & 1.672 & 1.598 & 1.543 & 1.498 \\ 1.461 & 1.424 & 1.400 & 1.375 & 1.351 & 1.326 & 1.325 & 1.321 \\ 1.321 & 1.323 & 1.338 & 1.353 & 1.384 & 1.400 & 1.420 & 1.460 \\ 1.477 & 1.516 & 1.537 & 1.555 & 1.800 & 1.800 & 1.800 & 1.800 \\ 1.799 & 1.799 & 1.799 & 1.799 & 1.798 & 1.798 & 1.798 & 1.798 \\ 1.797 & 1.797 & 1.797 & 1.797 & 1.796 & 1.796 & 1.796 & 1.796 \\ 1.795 & 1.795 & 1.795 & 1.795 & 1.794 & 1.794 & 1.794 & 1.794 \\ 1.793 & 1.793 & 1.793 & 1.793 & 1.792 & 1.792 & 1.792 & 1.792 \\ 1.791 & 1.791 & 1.791 & 1.791 & 1.790 & 1.790 & 1.790 & 1.790 \\ 1.789 & 1.789 & 1.789 & 1.789 & 1.783 & 1.788 & 2.126 & 2.094 \\ 2.071 & 2.063 & 2.056 & 2.047 & 2.041 & 2.251 & 2.230 & 2.211 \\ 2.190 & 2.169 & 2.147 & 2.124 & 2.100 & 2.076 & 2.051 & 2.025 \\ 1.944 & & & & & & & \end{array}$

Cell current of last driving profile:

$\begin{array}{lllllllll}35.449 & 72.930 & 112.974 & 156.236 & 203.586 & 255.591 & 293.592 & 324.944\end{array}$ $\begin{array}{lllllllll}350.294 & 375.739 & 391.674 & 406.386 & 419.935 & 433.654 & 430.279 & 429.191\end{array}$

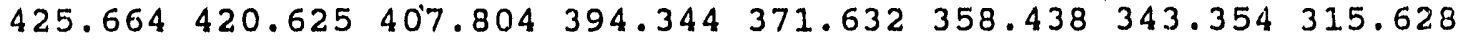

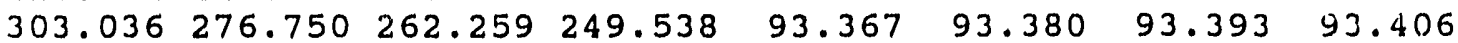

$\begin{array}{llllllll}93.419 & 93.432 & 93.445 & 93.459 & 93.472 & 93.485 & 93.498 & 93.511\end{array}$

$\begin{array}{llllllll}93.524 & 93.537 & 93.550 & 93.563 & 93.576 & 93.589 & 93.603 & 93.616\end{array}$

$\begin{array}{llllllll}93.629 & 93.642 & 93.655 & 93.668 & 93.682 & 93.695 & 93.708 & 93.721\end{array}$

$\begin{array}{llllllll}93.734 & 93.748 & 93.761 & 93.774 & 93.787 & 93.801 & 93.814 & 93.827\end{array}$

$\begin{array}{llllllll}93.840 & 93.854 & 93.867 & 93.880 & 93.894 & 93.907 & 93.920 & 93.934\end{array}$

$\begin{array}{lllllll}93.947 & 93.960 & 93.974 & 93.987 & 94.000 & 94.014-1.31 .128 & -98.802\end{array}$

$-75.148-66.704-59.230-50.662-43.653-259.823-239.044-219.316$

$-197.850-175.394-152.797-129.129-104.420-79.719-53.937-27.206$ .000

Projected maximum range is Capacity removed is Regeneration capacity is $\begin{aligned} 69.960 \mathrm{~km}( & 43.480 \mathrm{miles}) \\ 11.474 \mathrm{kWh} & \text { or } 138.772 \mathrm{Ah} \\ 2.544 \mathrm{kWh} & \text { or } 25.377 \mathrm{Ah}\end{aligned}$ 
SAMPLE 2: Same as SAMPLE-1 Except Power Profile is Input (Cont'd)

\begin{tabular}{|c|c|c|c|c|}
\hline Time (s) & $\mathrm{km} / \mathrm{h}$ & $\mathrm{mph}$ & $\mathrm{km}$ & mile \\
\hline 1 & 20.11 & 12.50 & .00 & .00 \\
\hline 2 & 32.49 & 20.20 & .01 & .01 \\
\hline 3 & 41.93 & 26.06 & .02 & .01 \\
\hline 4 & 49.77 & 30.93 & .03 & .02 \\
\hline 5 & 56.57 & 35.16 & .05 & .03 \\
\hline 6 & 62.65 & 38.94 & .06 & .04 \\
\hline 7 & 68.15 & 42.35 & .08 & .05 \\
\hline 8 & 73.18 & 45.48 & .10 & .06 \\
\hline 9 & 77.82 & 48.37 & .12 & .08 \\
\hline 10 & 82.15 & 51.06 & .15 & .09 \\
\hline 11 & 86.19 & 53.57 & .17 & .10 \\
\hline 12 & 90.02 & 55.95 & .19 & .12 \\
\hline 13 & 93.62 & 58.19 & .22 & .14 \\
\hline 14 & 97.03 & 60.31 & .25 & .15 \\
\hline 15 & 100.26 & 62.31 & .27 & .17 \\
\hline 16 & 103.33 & 64.22 & .30 & .19 \\
\hline 17 & 106.25 & 66.04 & .33 & .21 \\
\hline 18 & 109.03 & 67.77 & .36 & .22 \\
\hline 19 & 111.69 & 69.42 & .39 & .24 \\
\hline 20 & 114.23 & 71.00 & .42 & .26 \\
\hline 21 & 116.66 & 72.51 & .45 & .28 \\
\hline 22 & 119.01 & 73.97 & .49 & .30 \\
\hline 23 & 121.26 & 75.37 & .52 & .32 \\
\hline 24 & 123.42 & 76.71 & .55 & .34 \\
\hline 25 & 125.50 & 78.00 & .59 & .37 \\
\hline 26 & 127.48 & 79.23 & .62 & .39 \\
\hline 27 & 1.29 .39 & 80.42 & .66 & .41 \\
\hline
\end{tabular}

This is the end of the case. 
SAMPLE 3: Same as SAMPLE-1 Except RF $=1.1, I P I N=0$, and $I A C C=0$

SAMPLE-3: Same AS SAMPLE-1 Except RF $=1.1$, IPIN $=0$, and IACC $=0$

\begin{tabular}{|c|c|}
\hline \multicolumn{2}{|l|}{ enicle type } \\
\hline $\begin{array}{l}\text { Drive cycle } . \\
\text { Battery type }\end{array}$ & J227aD \\
\hline $\begin{array}{l}\text { Battery type } \cdots \cdots \cdots \cdots \cdots \\
\text { Test wt. of } \mathrm{EV},(\mathrm{kg}), \mathrm{TW}\end{array}$ & $3 \mathrm{ET} 205$ \\
\hline $\begin{array}{l}\text { Test wt. of EV, }(\mathrm{kg}), \mathrm{TW} \\
\text { Battery wt. , (kg), BW } \ldots\end{array}$ & $\begin{array}{r}1678.800 \\
488.000\end{array}$ \\
\hline Net cell wt., (kg), wC .. & 10.930 \\
\hline Accessory wt./cell, (kg), WY & .000 \\
\hline No. of cells in battery, NC & 44.648 \\
\hline No. of parallel strings in $b$ & 1.000 \\
\hline Cell amp-hours a $\mathrm{c} / 3, \mathrm{c} 3 \ldots$ & 186.000 \\
\hline Peak power demand, $(W / \mathrm{kg}) \ldots$ & 52.586 \\
\hline$(\mathrm{kW}) \quad \ldots \ldots \ldots \ldots \ldots \ldots \ldots$ & 25.662 \\
\hline $\begin{array}{r}\text { Battery peak power at } 100 \% \text { SOC }(\mathrm{W} / \mathrm{kg}) \ldots \\
\text { and } 2 / 3-\mathrm{NLV},(\mathrm{kW}) \ldots \ldots\end{array}$ & $\begin{array}{l}85.438 \\
41.694\end{array}$ \\
\hline sistance factor for aging, $R F$...... & 1.100 \\
\hline o-load voltage factor, VF ..... & 1.000 \\
\hline
\end{tabular}

\begin{tabular}{|c|c|c|c|c|c|c|c|c|c|}
\hline Driving & Time & Range & \multicolumn{2}{|c|}{ Maximum I } & \multicolumn{2}{|c|}{ Minimum V } & \multicolumn{2}{|c|}{ Amp-Hour } & kWh \\
\hline Profile & $\mathrm{h}$ & $\mathrm{km}$ & Cell & Batt & Cell & Batt & Celi & Batt & Batt \\
\hline 1 & .03 & 1.6 & 326.1 & 326.1 & 1.763 & 78.7 & 3.1 & 3.1 & .3 \\
\hline 2 & .07 & 3.2 & 320.6 & 320.6 & 1.793 & 80.0 & 6.1 & 6.1 & .5 \\
\hline 3 & .10 & 4.8 & 315.7 & 315.7 & 1.821 & 81.3 & 9.1 & 9.1 & .8 \\
\hline 4 & .14 & 6.4 & 315.0 & 315.0 & 1.824 & 81.5 & 12.1 & 12.1. & 1.0 \\
\hline 5 & .17 & 7.9 & 315.6 & 315.6 & 1.821 & 81.3 & 15.1 & 15.1 & 1.3 \\
\hline 6 & .20 & 9.5 & 316.3 & 316.3 & 1.817 & 81.1 & 18.1 & 18.1 & 1.6 \\
\hline 7 & .24 & 11.1 & 316.9 & 316.9 & 1.814 & 81.0 & 21.1 & 21.1 & 1.8 \\
\hline 8 & .27 & 12.7 & 317.5 & 317.5 & 1.810 & 80.8 & 24.1 & 24.1 & 2.1 \\
\hline 9 & .31 & 14.3 & 318.1 & 318.1 & 1.807 & 80.7 & 27.2 & 27.2 & 2.3 \\
\hline 10 & .34 & 15.9 & 318.8 & 318.8 & 1.803 & 80.5 & 30.2 & 30.2 & 2.6 \\
\hline 11 & .37 & 17.5 & 319.4 & 319.4 & 1.800 & 80.3 & 33.2 & 33.2 & 2.9 \\
\hline 12 & .41 & 19.1 & 320.0 & 320.0 & 1.796 & 80.2 & 36.3 & 36.3 & 3.1 \\
\hline 13 & .44 & 20.7 & 320.7 & 320.7 & 1.792 & 80.0 & 39.3 & 39.3 & 3.4 \\
\hline 14 & .47 & 22.2 & 321.3 & 321.3 & 1.789 & 79.9 & 42.4 & 42.4 & 3.7 \\
\hline 15 & .51 & 23.8 & 322.0 & 322.0 & 1.785 & 79.7 & 45.5 & 45.5 & 3.9 \\
\hline 16 & .54 & 25.4 & 322.7 & 322.7 & 1.781 & 79.5 & 48.5 & 48.5 & 4.2 \\
\hline 17 & .58 & 27.0 & 323.7 & 323.7 & 1.776 & 79.3 & 51.6 & 51.6 & 4.4 \\
\hline 18 & .61 & 28.6 & 324.7 & 324.7 & 1.770 & 79.0 & 54.7 & 54.7 & 4.7 \\
\hline 19 & .64 & 30.2 & 325.8 & 325.8 & 1.764 & 78.8 & 57.8 & 57.8 & 5.0 \\
\hline 20 & .68 & 31.8 & 326.8 & 326.8 & 1.759 & 78.5 & 60.9 & 60.9 & 5.2 \\
\hline 21 & .71 & 33.4 & 328.0 & 328.0 & 1.752 & 78.2 & 64.0 & 64.0 & 5.5 \\
\hline 22 & .75 & 35.0 & 330.0 & 330.0 & 1.742 & 77.8 & 67.1 & 67.1 & 5.7 \\
\hline 23 & .78 & 36.5 & 332.0 & 332.0 & 1.731 & 77.3 & 70.2 & 70.2 & 6.0 \\
\hline 24 & .81 & 38.1 & 334.1 & 334.1 & 1.720 & 76.8 & 73.4 & 73.4 & 6.3 \\
\hline 25 & .85 & 39.7 & 336.2 & 336.2 & 1.710 & 76.3 & 76.6 & 76.6 & 6.5 \\
\hline 26 & .88 & 41.3 & 338.4 & 338.4 & 1.699 & 75.8 & 79.7 & 79.7 & 6.8 \\
\hline 27 & .92 & 42.9 & 340.7 & 340.7 & 1.687 & 75.3 & 82.9 & 82.9 & 7.0 \\
\hline 28 & .95 & 44.5 & 343.0 & 343.0 & 1.676 & 74.8 & 86.1 & 86.1 & 7.3 \\
\hline 29 & .98 & 46.1 & 345.4 & 345.4 & 1.664 & 74.3 & 89.4 & 89.4 & 7.6 \\
\hline 30 & 1.02 & 47.7 & $34 \% .9$ & 347.5 & 1.652 & 73.6 & S2. & 32.6 & 7.8 \\
\hline
\end{tabular}


SAMPLE 3: Same as SAMPLE-1 Except $R F=1.1, I P I N=0$, and $I A C C=0$ (Cont'd)

$\begin{array}{rcrrrrrrrr}31 & 1.05 & 49.3 & 351.3 & 351.3 & 1.636 & 73.1 & 95.9 & 95.9 & 8.1 \\ 32 & 1.08 & 50.8 & 355.3 & 355.3 & 1.618 & 72.2 & 99.2 & 99.2 & 8.3 \\ 33 & 1.12 & 52.4 & 359.5 & 359.5 & 1.599 & 71.4 & 102.5 & 102.5 & 8.6 \\ 34 & 1.15 & 54.0 & 364.0 & 364.0 & 1.579 & 70.5 & 105.8 & 105.8 & 8.9 \\ 35 & 1.19 & 55.6 & 368.8 & 368.8 & 1.559 & 69.6 & 109.2 & 109.2 & 9.1 \\ 36 & 1.22 & 57.2 & 373.7 & 373.7 & 1.538 & 68.7 & 112.6 & 112.6 & 9.4 \\ 37 & 1.25 & 58.8 & 378.9 & 378.9 & 1.517 & 67.7 & 116.0 & 116.0 & 9.6 \\ 38 & 1.29 & 60.4 & 384.5 & 384.5 & 1.495 & 66.7 & 129.5 & 119.5 & 9.9 \\ 39 & 1.32 & 62.0 & 390.8 & 390.8 & 1.471 & 65.7 & 123.0 & 123.0 & 10.2 \\ 40 & 1.36 & 63.6 & 404.9 & 404.9 & 1.420 & 63.4 & 126.5 & 126.5 & 10.4 \\ 41 & 1.39 & 65.1 & 422.5 & 422.5 & 1.360 & 60.7 & 130.2 & 130.2 & 10.7 \\ \text { Driving } & \text { Time } & \text { Range } & \text { Maximum I } & \text { Minimum V } & \text { Amp-Hour } & \text { kWh } \\ \text { Profile } & \mathrm{h} & \text { km } & \text { Cell } & \text { Batt } & \text { Cell } & \text { Batt } & \text { Cell } & \text { Batt } & \text { Batt }\end{array}$

$\begin{array}{cccccccc}\text { Ce11. voltage of } & \text { first driving profile: } \\ 2.111 & 2.071 & 2.029 & 1.984 & 1.938 & 1.889 & 1.856 & 1.830 \\ 1.810 & 1.792 & 1.782 & 1.774 & 1.768 & 1.0763 & 1.768 & 1.771 \\ 1.777 & 1.782 & 1.793 & 1.803 & 1.820 & 1.830 & 1.842 & 1.862 \\ 1.873 & 1.893 & 1.905 & 1.916 & 2.056 & 2.056 & 2.056 & 2.056 \\ 2.056 & 2.056 & 2.056 & 2.056 & 2.056 & 2.056 & 2.056 & 2.056 \\ 2.056 & 2.056 & 2.056 & 2.056 & 2.056 & 2.056 & 2.056 & 2.056 \\ 2.056 & 2.056 & 2.056 & 2.057 & 2.057 & 2.057 & 2.057 & 2.057 \\ 2.057 & 2.057 & 2.057 & 2.057 & 2.057 & 2.057 & 2.057 & 2.057 \\ 2.057 & 2.057 & 2.057 & 2.057 & 2.057 & 2.057 & 2.057 & 2.057 \\ 2.057 & 2.057 & 2.057 & 2.057 & 2.058 & 2.058 & 2.519 & 2.489 \\ 2.467 & 2.460 & 2.453 & 2.445 & 2.439 & 2.640 & 2.621 & 2.603 \\ 2.583 & 2.562 & 2.541 & 2.520 & 2.497 & 2.474 & 2.451 & 2.427 \\ 2.150 & & & & & & & \end{array}$

Cell current of first driving profile:

$\begin{array}{rrrrrrrr}32.076 & 65.448 & 100.325 & 136.963 & 175.680 & 216.211 & 244.212 & 266.076 \\ 282.736 & 298.524 & 307.773 & 314.927 & 320.784 & 326.104 & 322.525 & 320.108 \\ 316.562 & 312.274 & 304.278 & 295.962 & 282.596 & 274.283 & 264.765 & 247.454 \\ 239.022 & 221.548 & 211.486 & 202.492 & 81.800 & 81.798 & 81.796 & 81.795 \\ 81.793 & 81.792 & 81.790 & 81.788 & 81.787 & 81.785 & 81.784 & 81.782 \\ 81.780 & 81.779 & 81.777 & 81.776 & 81.774 & 81.772 & 81.771 & 81.769 \\ 81.768 & 81.766 & 81.764 & 81.763 & 81.761 & 81.760 & 81.758 & 81.756 \\ 81.755 & 81.753 & 81.752 & 81.750 & 81.748 & 81.747 & 81.745 & 81.744 \\ 81.742 & 81.741 & 81.739 & 81.737 & 81.736 & 81.734 & 81.733 & 81.731 \\ 81.729 & 81.728 & 81.726 & 81.725 & 81.723 & 81.721-110.641 & -83.140 \\ -63.089 & -55.956 & -49.640 & -42.403 & -36.506-221.472-203.416-186.312 \\ -167.800-148.445-129.080-108.861 & -87.824 & -66.889 & -45.129 & -22.714 \\ .000 & & & & & & & \end{array}$


SAMPLE 3: Same as SAMPLE-1 Except RF $=1.1, \mathrm{IPIN}=0$, and IACC $=0$ (Cont'd)

\begin{tabular}{llllllll} 
Cell voltage of & \multicolumn{7}{c}{ last driving profile: } \\
1.932 & 1.878 & 1.821 & 1.759 & 1.691 & 1.616 & 1.561 & 1.515 \\
1.478 & 1.440 & 1.416 & 1.396 & 1.378 & 1.360 & 1.367 & 1.370 \\
1.376 & 1.385 & 1.403 & 1.421 & 1.452 & 1.469 & 1.489 & 1.526 \\
1.543 & 1.579 & 1.599 & 1.616 & 1.838 & 1.838 & 1.837 & 1.837 \\
1.837 & 1.837 & 1.837 & 1.837 & 1.837 & 1.837 & 1.837 & 1.837 \\
1.837 & 1.836 & 1.836 & 1.836 & 1.836 & 1.836 & 1.836 & 1.836 \\
1.836 & 1.836 & 1.836 & 1.835 & 1.835 & 1.835 & 1.835 & 1.835 \\
1.835 & 1.835 & 1.835 & 1.835 & 1.835 & 1.835 & 1.834 & 1.834 \\
1.834 & 1.834 & 1.834 & 1.834 & 1.834 & 1.834 & 1.834 & 1.834 \\
1.833 & 1.833 & 1.833 & 1.833 & 1.833 & 1.833 & 2.143 & 2.110 \\
2.086 & 2.077 & 2.069 & 2.061 & 2.054 & 2.274 & 2.253 & 2.233 \\
2.211 & 2.188 & 2.165 & 2.141 & 2.116 & 2.091 & 2.064 & 2.037 \\
1.972 & & & & & & &
\end{tabular}

Cell current of last driving profile:

$\begin{array}{rrrrrrrr}35.052 & 72.160 & 111.781 & 154.546 & 201.367 & 252.801 & 290.391 & 321.403 \\ 346.409 & 371.497 & 387.317 & 400.329 & 411.654 & 422.521 & 417.168 & 413.928 \\ 408.614 & 401.972 & 388.873 & 375.513 & 354.244 & 341.613 & 327.362 & 301.894 \\ 289.987 & 265.625 & 252.021 & 240.058 & 91.501 & 91.505 & 91.510 & 91.515 \\ 91.519 & 91.524 & 91.529 & 91.534 & 91.538 & 91.543 & 91.548 & 91.552 \\ 91.557 & 91.562 & 91.567 & 91.571 & 91.576 & 91.581 & 91.586 & 91.590 \\ 91.595 & 91.600 & 91.605 & 91.609 & 91.614 & 91.619 & 91.623 & 91.628 \\ 91.633 & 91.638 & 91.642 & 91.647 & 91.652 & 91.657 & 91.661 & 91.666 \\ 91.671 & 91.676 & 91.680 & 91.685 & 91.690 & 91.695 & 91.699 & 91.704 \\ 91.709 & 91.714 & 91.718 & 91.723 & 91.728 & 91.733-130.045 & -98.078 \\ -74.633 & -66.264 & -58.841 & -50.316 & -43.358-257.166-236.668-217.188 \\ 196.030-173.823-151.511-128.111-103.644 & -79.168 & -53.580 & -27.058 \\ .000 & & & & & & & \end{array}$

Projected maximum range is Capacity removed is

$65.145 \mathrm{~km}$ ( 40.488 miles)

Regeneration capacity is

$10.693 \mathrm{kWh}$

or $130.169 \mathrm{Ah}$

$2.429 \mathrm{kWh}$ or $24.061 \mathrm{Ah}$

This is the end of the case. 

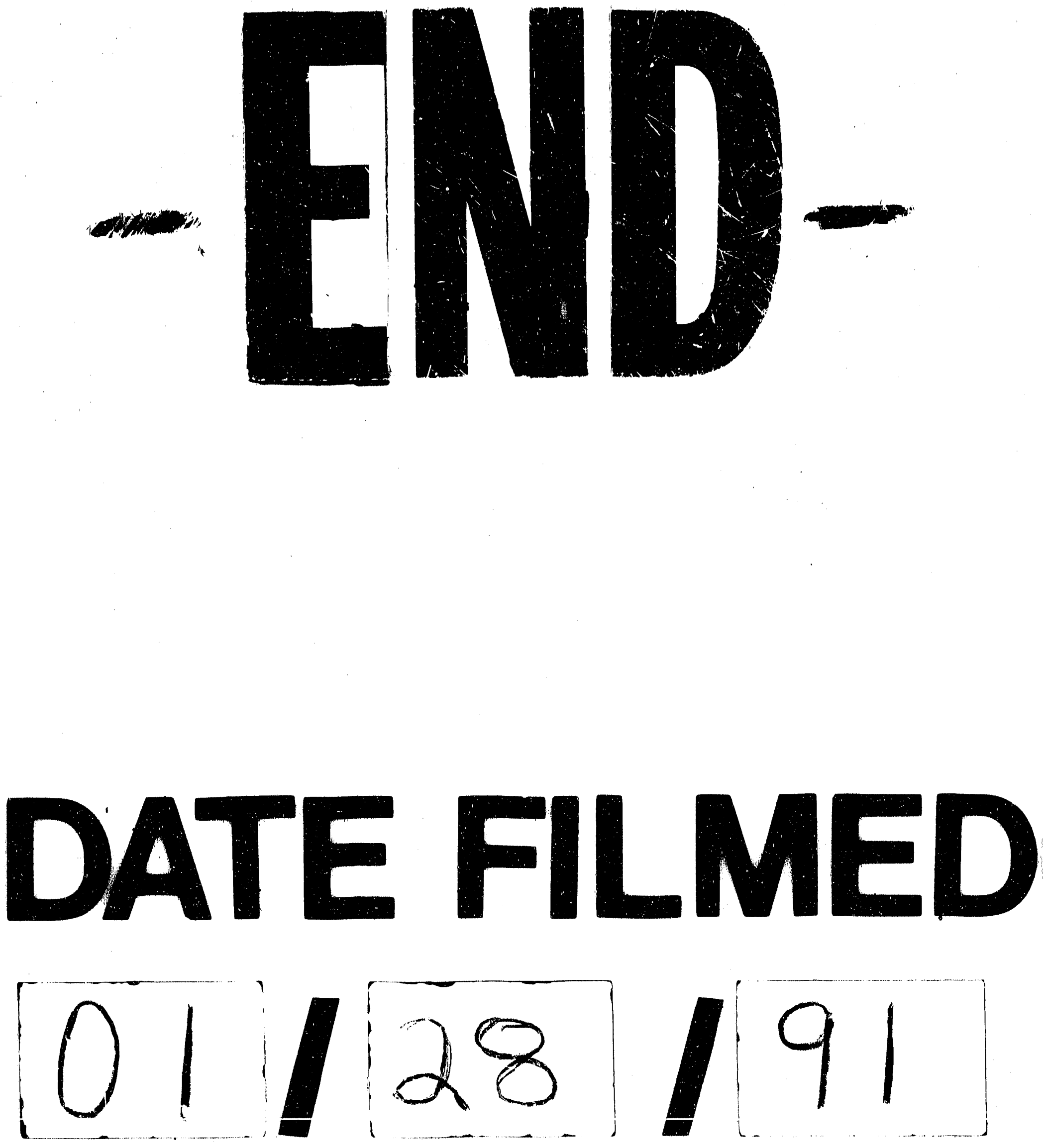
